Working papers series

WP ECON 19.11

\title{
Education and adult health: Is there a causal effect?
}

\author{
Pedro Albarrán \\ Universidad de Alicante \\ Marisa Hidalgo-Hidalgo \\ Universidad Pablo de Olavide \\ Iñigo I turbe-Ormaetxe \\ Universidad de Alicante
}

Keywords: health; education; instrumental variables.

JEL Classification: 112, 121 


\title{
Education and adult health: Is there a causal effect? *
}

Pedro Albarrán

Fundamentos del Análisis Económico (FAE)

Universidad de Alicante
Marisa Hidalgo-Hidalgo

Dpto. Economía, Métodos Cuantitativos e

Historia Económica

Universidad Pablo de Olavide de Sevilla

\author{
Iñigo Iturbe-Ormaetxe** \\ Fundamentos del Análisis Económico (FAE) \\ Universidad de Alicante
}

\begin{abstract}
Many studies find a strong positive correlation between education and adult health. A subtler question is whether this correlation can be interpreted as a causal relationship. We combine multi-country data from two cross-sections of EU-SILC (European Union Statistics on Income and Living Conditions) and use exogenous variation in compulsory years of schooling across countries and cohorts induced by compulsory school laws. We find no causal effect of education on any of our several health measures. This finding is extremely robust to different changes in our main specification and holds using other databases. We discuss different explanations.
\end{abstract}

Keywords: health; education; instrumental variables

JEL Classification: I12, I21

* We thank Giorgio Brunello, Elena Martínez-Sanchís, Climent Quintana-Domeque, and Ian Walker for helpful comments. Financial support from Ministerio de Economía y Competitividad and Feder (ECO2014-57413, ECO2015-65820-P, ECO2017-83069-P), Ministerio de Educación, Cultura y Deporte (programa estatal de promoción del talento y su empleabilidad en $\mathrm{I}+\mathrm{D}+\mathrm{i}$, subprograma estatal de movilidad, plan estatal de investigación científica y técnica y de innovación 2013-16), Generalitat Valenciana (Prometeo/2019/037) and Instituto Valenciano de Investigaciones Económicas (IVIE) is gratefully acknowledged. 

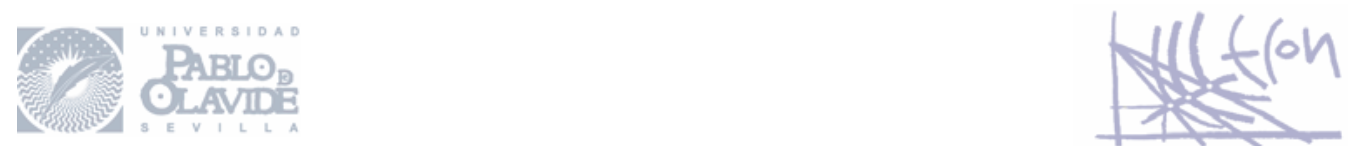

\section{Introduction}

A large number of works have documented that people with a high educational level have consistently better health than those with a low educational level. No matter which measure of health is used, the evidence of a strong correlation is pervasive (Grossman 2006, 2008; Cutler and Lleras-Muney, 2006; Oreopoulos, 2006 or Eide and Showalter, 2011). A subtler point is whether this correlation can be interpreted as a causal relationship, and which is its direction.

A common identification strategy to analyze the impact of education on health consists of instrumenting education, using compulsory schooling laws (CSL) that increase the minimum school leaving age. ${ }^{1}$ As far as we know, Lleras-Muney (2005) is the first work using CSL to identify the effect of education on mortality in the USA. Several authors have used a similar approach using data from specific countries, while others use a multi-country approach exploiting variation induced by reforms across both birth cohorts and countries. The overall picture is not conclusive. Some studies find a positive and significant effect of education on health for specific countries, as Oreopoulos (2006) Silles (2009) or Powdthavee (2010) in the UK, Van Kippersluis et al. (2011) for The Netherlands, Kemptner et al. (2011) in Germany, Fischer et al. (2013) in Sweden. Brunello et al. (2013), Crespo et al. (2014), Mazzona (2014), Gathmann et al. (2015) and Brunello et al. (2016) also find positive effects using a multi-country approach. On the other side, several studies do not find a causal effect as Arendt (2005) in Denmark, Albouy and Lequien (2009) in France, Jürges et al. (2013) and Clark and Royer (2013) in the UK, Fletcher (2015) in the USA, Meghir et al. (2018) in Sweden, Malamud et al. (2018) in Romania, or Courtin et al. (2019) in

\footnotetext{
${ }^{1}$ To get a good approximation to this topic see Lochner (2011), Cutler and Lleras-Muney (2012) and Galama et al. (2018).
} 

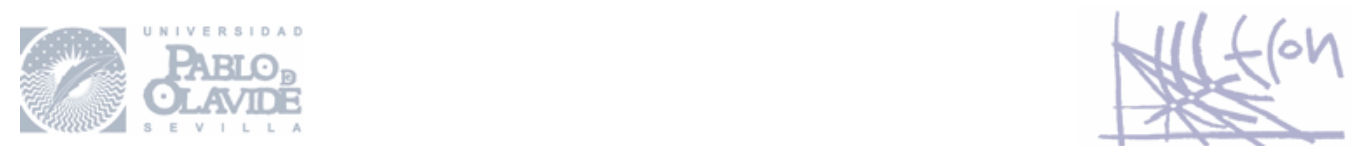

France. Finally, some studies find a positive effect on some health outcomes, and not on others. Janke et al. (2018) find that education in the UK has little impact on the prevalence of chronic illness, with the exception of diabetes, while Davies et al. (2018) find that education reduces the risk of diabetes and mortality. ${ }^{2}$

We present new evidence on the possible causal effect of education on health using multi-country data from the 2005 and 2011 cross sections of EU-SILC (European Union Statistics on Income and Living Conditions). This is a rich database with information on education and health for the European countries. Additionally, the 2005 and 2011 cross sections include retrospective information on family background, which gives us information on socio-economic status (SES) when the individual was young. Our main result is that we do not find a causal effect of education on any of our three health measures. Our estimated IV coefficients are similar in magnitude to OLS coefficients, but statistically insignificant since standard errors are, as usual, larger for IV. Due to this lack of precision we cannot exclude neither the small effect obtained by OLS nor large effects. We also explore the possibility of heterogeneous effects of education on health for different groups. Nevertheless, we get the same negative result when we focus on different subgroups, according to sex, parental education, or family income.

Our results are robust to different changes in our main specification. We discuss alternative explanations for why education may have no causal effect on health even if, as we see, it does affect income positively. For instance, according to the cumulative (dis)advantages hypothesis, differences in exposure and vulnerability to health risks imply a widening intra-cohort health gap between lower and higher educated

\footnotetext{
${ }^{2}$ See the recent review of this literature by Hamad et al. (2018).
} 


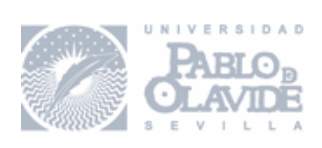

individuals and thus differences in health between individuals of different educational levels are only present at a relatively high age. ${ }^{3}$ As our sample is relatively younger than in previous works, this could explain why we do not find a significant effect of education on health, while some previous works do.

In addition, the exogenous variation we exploit occurs at the level of secondary education. We cannot rule out that additional schooling in other educational stages might have a positive impact on health. Moreover, we also find that a large part of the increase in education occurs in countries where the quality of education was not very good.

Overall, we note that in developed countries with well-functioning public health systems there are not great differences in health outcomes according to education. Even if more education entails higher earnings, differences in income are not crucial to having access to a better medical care. Our result could be interpreted as a lack of inequality in health outcomes by educational levels, which could be seen as good news.

We contribute to the literature in several respects. First, we exploit a rich dataset that has information from several European countries. The sample is quite homogeneous in terms of years of birth. Indeed, we are the first using a multi-country approach in a recent literature which find no conclusive causal effects of education of health. By using this approach, we can compare only those countries where the instrument works, that is, where CSL have a clear positive effect on education. This represents a differential approach with respect to the previous literature to the extent that we choose the most favorable scenario to obtain a positive effect of education. This allows us to identify an upper bound to the causal effect of education on health

\footnotetext{
${ }^{3}$ Delaruelle et al. (2015) and Leopold and Leopold (2018) report evidence in favor of this hypothesis.
} 

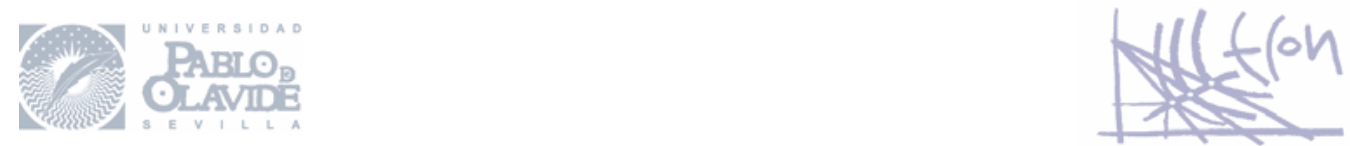

outcomes. Second, the 2005 and 2011 cross sections of EU-SILC contain rich information describing family characteristics before individuals finish compulsory education. This allows us to explore whether educational reforms have heterogeneous effects on individuals' schooling, as some recent literature suggests (Brunello et al., 2013 or Crespo et al., 2014). Since education can affect differently people of different SES or gender and, given that average effects capture the combined effect in them, it is also important to disentangle the impact of education on health for different groups. In particular, we consider dimensions pointed out as relevant by previous literature: gender, family economic background (poor/non-poor families) and family socio-cultural background (non-educated/educated families). Third, our dataset contains three different measures of health status including self-reported health, chronic illness and limitation in daily activities. We also use an alternative dataset, the European Social Survey (ESS) that, though less detailed, contains information on education and health outcomes. Our use of different health measures and databases ensures that our results are not specific to a measure or data set.

\section{Data and empirical strategy}

We use data from the 2005 and 2011 cross sections of EU-SILC (EU Statistics on Income and Living Conditions). EU-SILC contains information on income, education, health, poverty, social exclusion and living conditions in the European Union. ${ }^{4}$ The 2005 and 2011 cross sections include special modules on intergenerational transmission of disadvantages with retrospective information on the characteristics of the family in which individuals were raised: family composition, occupation and

\footnotetext{
${ }^{4}$ For an overview of EU-SILC, see Wolff et al. (2010). More information provided by GESIS at http://www.gesis.org/
} 

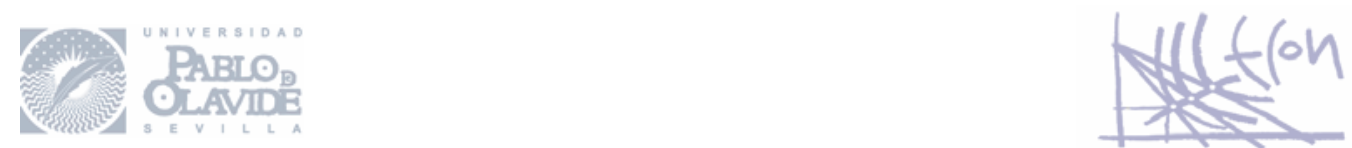

educational level of parents, and information about the economic situation in the household when the individual was a teenager. Since we use these modules, we have to exclude all individuals who are not in the age range of the modules or are not the selected respondent. ${ }^{5}$ This restricts our sample to individuals born after 1939 . We exclude individuals who did not live with their parents. Finally, we exclude all individuals not born in the country of residence, since we do not know where they went to school.

Our database includes twelve countries in EU-SILC for which we have reliable information about CSL: Austria, Czech Republic, France, Greece, Ireland, Italy, Malta, The Netherlands, Poland, Portugal, Slovakia, and United Kingdom. We exclude countries for which we lack information on CSL (Bulgaria, Cyprus, Estonia, Croatia, Iceland, Latvia, Lithuania, Luxembourg, Romania and Slovenia), or whose CSL were implemented gradually through several years or at the regional/local level (Finland, Norway, Sweden and Switzerland). We exclude Germany since the reforms we are aware of were implemented gradually at the regional level, since EU-SILC lacks regional identifiers for Germany. ${ }^{6}$ We exclude Belgium because the reform (1983) was much later. Finally, we exclude three countries (Denmark, Spain, and Hungary) other authors have used because we find no effect of the CSL proposed by other authors on educational levels. The inclusion of these countries would only exacerbate any potential bias of our IV estimates towards OLS. Nevertheless, in the Online Appendix we show our results are robust to the inclusion of these three countries.

\footnotetext{
${ }^{5}$ The intergenerational modules exclude individuals who are not the selected respondent in register countries and those not in the age range (26-66).

${ }^{6}$ Using reforms at the regional level requires to assume that subjects living in a region at the time of the survey went to school in that same region.
} 
Table 1: Reforms in compulsory education

\begin{tabular}{lcccc}
\hline Country & $\begin{array}{c}\text { Year of } \\
\text { reform }\end{array}$ & $\begin{array}{c}\text { First } \\
\text { cohort } \\
\text { affected }\end{array}$ & $\begin{array}{c}\text { Change in } \\
\text { years of } \\
\text { compulsory } \\
\text { education }\end{array}$ & $\begin{array}{c}\text { School } \\
\text { entry age }\end{array}$ \\
Austria & 1966 & 1953 & 8 to 9 & 6 \\
Czech Rep./Slovakia & 1960 & 1946 & 8 to 9 & 6 \\
France & 1967 & 1953 & 8 to 10 & 6 \\
Greece & 1976 & 1964 & 6 to 9 & 6 \\
Ireland & 1972 & 1958 & 8 to 9 & 6 \\
Italy & 1963 & 1951 & 5 to 8 & 6 \\
Malta & 1972 & 1960 & 8 to 10 & 5 \\
Netherlands & 1975 & 1959 & 9 to 10 & 7 \\
Poland & 1966 & 1952 & 7 to 8 & 7 \\
Portugal & 1964 & 1956 & 4 to 6 & 6 \\
UK & 1972 & 1957 & 10 to 11 & 6 \\
Additional reforms used only in the robustness check & \\
Denmark & 1971 & 1957 & 7 to 9 & 7 \\
Hungary & 1961 & 1947 & 8 to 10 & 6 \\
Spain & 1970 & 1957 & 6 to 8 & 6 \\
\hline Notes: See the Ong
\end{tabular}

Notes: See the Online Appendix for details on these reforms.

Table 1 displays our reforms. All of them increased compulsory schooling by one or more years. The first cohort potentially affected (FCA) goes from 1946 to 1964. In each country, the control group are the cohorts born before the FCA, and the treatment group includes the cohorts born after the FCA. With the exception of France, we follow Mocan and Pogorelova (2017) and exclude the FCA because the extent of this cohort's exposure to the education reform is unclear. See the Online Appendix for additional details of the reforms.

EU-SILC has three health questions: 1) “How is your health in general?” with five possible answers: “very good,” “good,” “fair,” "bad,” and “very bad”. We code this information into a dummy variable ("good health”) that is one when the answer is "very 

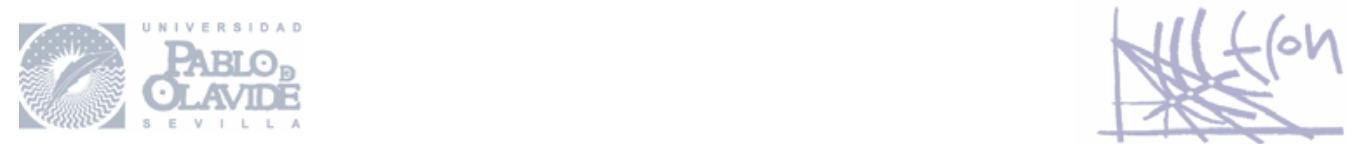

good” or "good.” 2) “Do you have any longstanding illness or health problem?” with two possible answers: “yes” and "no.” We build a dummy variable ("no chronic") that takes value one when the answer is no. 3) "For at least the last 6 months, to what extent have you been limited because of a health problem in activities people usually do?” The possible answers are "not limited," "limited," "very limited.” We build a third dummy variable ("not limited") that takes value one when the answer is not limited.

We use schooling years to measure education. EU-SILC reports the highest level of education attended, together with the year when that level was achieved. We exclude individuals still in education. Our measure (“years educ") is calculated as the year when the highest level was attained minus the year of birth minus school entry age. ${ }^{7}$ As an alternative measure, we use a dummy that takes value one when the individual has completed secondary education ("SE"). This variable may capture better than years educ if the individual has reached a certain level of competence. It can give a better idea of educational output than years of schooling, which measures just educational input.

In Figure 1, we represent our measures of health as a function of years of education. The age range is 25-66. The relationship between education and health

\footnotetext{
7 There are six educational levels in EU-SILC (pe040): 0 pre-primary; 1 primary; 2 lower secondary; 3 (upper) secondary; 4 post-secondary non-tertiary; 5 tertiary. A problem with this definition is that some individuals may complete their highest level of education when they are relatively old. For this reason, we exclude those subjects who have too many years of education, given their highest level of education achieved. We exclude individuals with pe040 $=1$ and more than 12 years of education, those with pe040 = 2 and more than 14 years of education, those with pe $040=3$ and more than 17 years of education, those with pe $040=4$ and more than 25 years of education, and those with pe040 $=5$ and more than 27 years of education. We also exclude individuals with too little education, given their education level: those with pe040 $=3$ and less than 10 years of education and those with pe040 $=5$ and less than 14 years of education. Finally, we exclude individuals with less than 4 years of education and those who ended education at the age of 35 or later.
} 
measures is not monotonic. It is increasing only up to 19 years. ${ }^{8}$ Given this evidence, we restrict our sample to individuals with at most 19 years of education. Including subjects with more than 19 years of education would make us easier to find a negative result (no effect of education on health outcomes). Our strategy is to select the worstcase scenario to get a negative result. $^{9}$

Figure 1: Average years of education and health measures

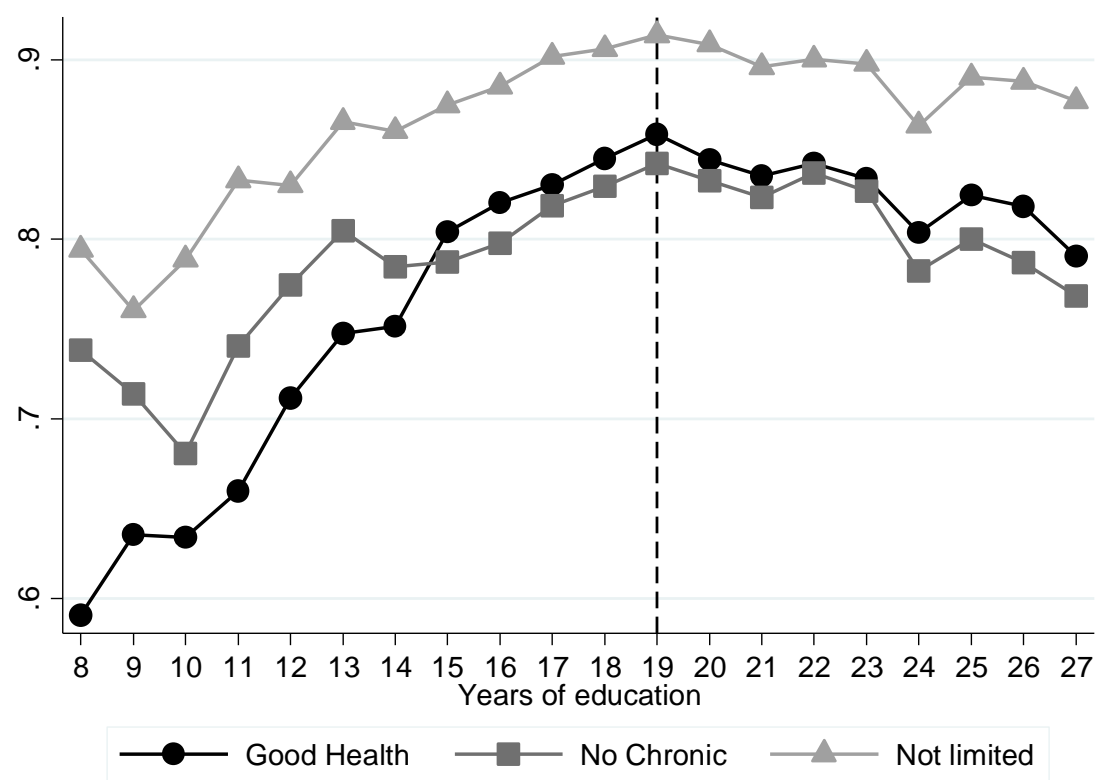

Other control variables capture early-life conditions. The survey has information on parental education, which has been shown to be the most important factor in explaining the education of children (see, among others, the review by Haveman and Wolfe, 1995). As a summary of family education, we build an indicator ("non-educated

\footnotetext{
${ }^{8}$ We find similar results dividing the sample into different age groups (25-34, 35-44, 45-54 and 55-66), separately by country, by gender and by SES. See the Online Appendix for additional figures.

${ }^{9}$ We also perform a robustness check by considering individuals with up to 27 years of education (the maximum in our sample). See the Online Appendix.
} 
family") that takes value one when the highest level of education of parents is primary education. ${ }^{10}$ We classify a family as "educated" when at least one of the parents has a secondary education or more. We use this variable not only as a control, but also to see whether the impact of CSL on individuals' schooling depends on parental education. We conjecture that this effect should depend on how much parents value children's education. Those individuals with educated parents are expected not to be the most affected by CSL, since they would surely have chosen more education than the reform imposes. On the contrary, for those from families with little education we should expect a stronger effect of CSL, since they are more likely to leave school right at the end of the compulsory period.

The survey contains information about the financial situation in the family when the individual was adolescent. We code this information into a dummy variable ("poor past") that is equal to one for those individuals who experienced frequent financial difficulties. We interpret this variable as a proxy of low parental SES.

Other explanatory (dummy) variables that we include in all our regressions are "father only" (= 1 if the mother was not present in the family), "noncitizen" (= 1 if the individual is not a citizen), and "CS2011" (= 1 if the observation corresponds to the 2011 cross section). Our sample consists of 47,269 individuals from 12 countries. A $53.4 \%$ belong to the 2005 wave (25,250 individuals) and the remaining $46.6 \%(22,019$ individuals) to the 2011 wave. See the Online Appendix for summary statistics on all variables used in the analysis.

\footnotetext{
${ }^{10}$ We get similar results using only the educational level of the mother or the father.
} 

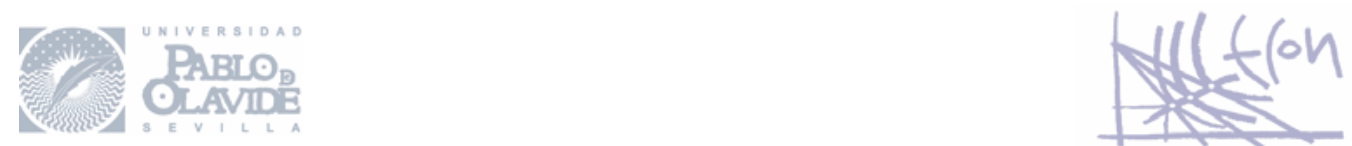

\section{Empirical model}

We use a two-equation model. The relationship of interest between education and health is the second-stage equation:

$$
H_{i}=\beta_{0}+\beta_{1} E_{i}+\beta_{2} X_{i}+v_{i}
$$

where $H_{i}$ is a measure of adult health, $E_{i}$ is education and $X_{i}$ includes a vector of individual and family characteristics determined before schooling is completed. We also add country and cohort fixed effects and country-specific quadratic trends in age. Country fixed effects control for invariant factors within countries, as national differences in institutions affecting health or in reporting styles. Given that treated individuals are always younger than controls, we need to include time trends since there is a secular positive tendency. In this way, we identify the effect of the reform on those individuals who, despite the positive trend, without such reform would not have acquired more education. Otherwise, we would be attributing to the reforms an effect that is simply a pure time effect (see Brunello et al., 2016 for a similar specification of time trends). ${ }^{11}$ Finally, we include an interaction term of CS2011 (the survey dummy) with the country dummies. The reason is that we use two cross sections, one from 2005 (pre-crisis) and one from 2011 (post-crisis). These interaction terms capture differential effects of the financial crisis across countries.

The error term in (1) is likely to contain unobserved individual characteristics that affect both education and health in the same direction. Estimating by OLS may yield biased estimators of the parameter of interest. To tackle this problem, we exploit the exogenous variation of schooling induced by changes in CSL that raised school

\footnotetext{
${ }^{11}$ As Lochner (2011) claims, without the inclusion of these trends secular improvements in health may be incorrectly attributed to school reforms, biasing the results. In addition, we know from Stephens and Yang (2014) that it is crucial that these time trends are country-specific.
} 


\section{Des}

leaving age. Our central measure of reform exposure is a dummy variable ("reform”) that takes value one for the affected cohorts. We also check our results using as alternative instrument the number of years of schooling that each cohort is required to attend by law. Control and treatment groups are country-specific. We face a trade-off when defining the number of year-of-birth cohorts included in each group. The larger is the number of cohorts included, the larger the sample size is. However, including many cohorts makes more difficult to assume that both groups are comparable. As a first approximation, we include seven cohorts in each group. Later on, we check the robustness of our results to the inclusion of fewer or more cohorts in both groups. ${ }^{12}$

Figure 2: Mean years of education according to distance (years) from the reform

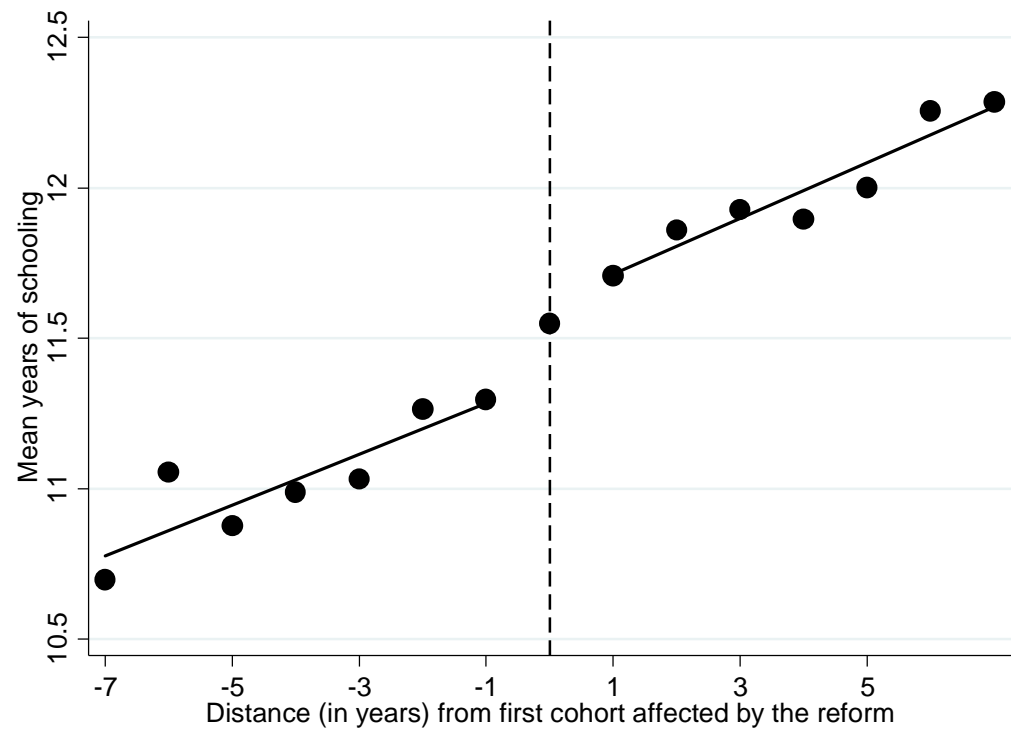

In Figure 2 we plot average values of years of schooling according to distance in years from the year of reform. Distance 0 corresponds to those born in Austria in 1952,

\footnotetext{
${ }^{12}$ As an example, consider the Austrian reform (1966) that increased school-leaving age from 14 to 15 . According to Gathmann et al. (2015), the FCA is 1953. This means that those born in Austria between 1946 and 1952 (control group), the reform dummy takes value 0, while for those born between 1954 and 1960 (treatment group) takes value 1 .
} 

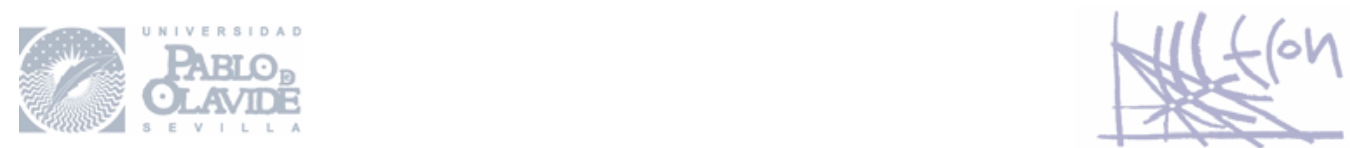

in the Czech Republic in 1946, etc. There is a jump upwards of about 0.3 years with respect to the trend, meaning that reforms have an impact on years of schooling (see also Brunello et al., 2013 and Brunello et al., 2016 for similar findings).

The key identification assumption is that, within each country, additional schooling was assigned to individuals only based on their birth date, and independently of future health. This can be justified since it is difficult to argue that exposure to the reform could have a direct effect on adult health, once we control for educational attainment of the individual, family economic and socio-cultural background characteristics, parents' education, and time trends. Our claim is that the effect of reforms on health operates indirectly through the schooling level of individuals.

The first-stage equation is:

$$
E_{i}=\gamma_{0}+\gamma_{1} R_{i}+\gamma_{2} X_{i}+\varepsilon_{i}
$$

where $R_{i}$ is either the reform dummy or the number of years of compulsory education corresponding to each individual.

The effect of education on health in (1) and reforms on schooling in (2) is homogeneous across individuals. However, we also estimate the model for different subgroups according to gender and family background.

\section{Results}

\subsection{First-Stage}

Table 2 presents our first-stage results using a 7-year window. The instrument is the reform dummy in Panel A, and the number of years of compulsory education in Panel B. In Column I, we estimate the model with all individuals and in columns II-VII we do it for six different sub-groups. The effect of CSL on education is positive and 

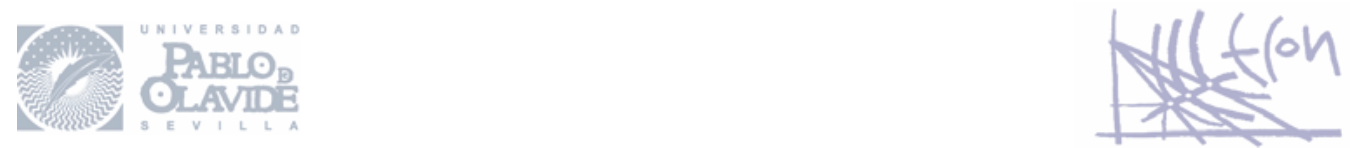

statistically significant, with an F-statistic above 10 in all cases, except for the subsample of individuals with educated parents. ${ }^{13}$

Table 2: First Stage

\begin{tabular}{|c|c|c|c|c|c|c|c|}
\hline & $\begin{array}{c}\text { I } \\
\text { All }\end{array}$ & $\begin{array}{c}\text { II } \\
\text { Men }\end{array}$ & $\begin{array}{c}\text { III } \\
\text { Women }\end{array}$ & $\begin{array}{c}\text { IV } \\
\text { Non } \\
\text { poor }\end{array}$ & $\begin{array}{c}\mathrm{V} \\
\text { Poor }\end{array}$ & $\begin{array}{c}\text { VI } \\
\text { Educated }\end{array}$ & $\begin{array}{c}\text { VII } \\
\text { Non } \\
\text { educated }\end{array}$ \\
\hline \multicolumn{8}{|c|}{ A. Reform dummy } \\
\hline $\begin{array}{l}\text { 1st stage } \\
\text { coefficient }\end{array}$ & $\begin{array}{c}0.368 * * * \\
(0.069)\end{array}$ & $\begin{array}{c}0.362 * * * \\
(0.098)\end{array}$ & $\begin{array}{c}0.367 * * * \\
(0.077)\end{array}$ & $\begin{array}{c}0.302^{* * *} \\
(0.087)\end{array}$ & $\begin{array}{c}0.496 * * * \\
(0.117)\end{array}$ & $\begin{array}{c}0.067 \\
(0.108)\end{array}$ & $\begin{array}{c}0.463 * * * \\
(0.077)\end{array}$ \\
\hline $\begin{array}{l}\text { 1st stage F- } \\
\text { test }\end{array}$ & 28.278 & 13.773 & 22.997 & 12.089 & 17.885 & 0.385 & 36.296 \\
\hline P-value & 0.000 & 0.000 & 0.000 & 0.001 & 0.000 & 0.536 & 0.000 \\
\hline \multicolumn{8}{|c|}{ B. Years of compulsory education } \\
\hline $\begin{array}{l}\text { 1st stage } \\
\text { coefficient }\end{array}$ & $\begin{array}{c}0.168 * * * \\
(0.040)\end{array}$ & $\begin{array}{c}0.184^{* * * *} \\
(0.056)\end{array}$ & $\begin{array}{c}0.153 * * * \\
(0.051)\end{array}$ & $\begin{array}{c}0.132 * * * \\
(0.045)\end{array}$ & $\begin{array}{c}0.227 * * * \\
(0.057)\end{array}$ & $\begin{array}{c}0.015 \\
(0.075)\end{array}$ & $\begin{array}{c}0.196 * * * \\
(0.045)\end{array}$ \\
\hline $\begin{array}{l}\text { 1st stage F- } \\
\text { test }\end{array}$ & 17.772 & 10.760 & 8.935 & 8.727 & 15.971 & 0.040 & 19.354 \\
\hline P-value & 0.000 & 0.001 & 0.003 & 0.004 & 0.000 & 0.842 & 0.000 \\
\hline Observations & 45,767 & 21,172 & 24,595 & 28,237 & 17,530 & 11,162 & 34,605 \\
\hline
\end{tabular}

Notes: All models include as controls noncitizen, father only, country-specific quadratic trends, cohort fixed effects, and country-specific survey effects. Model I includes as controls the dummies gender, non-educated family, and poor past, together with all their possible interactions. Models II-VII are for specific groups, and so the corresponding dummy variables are dropped.

Our first-stage results are in line with previous literature using a multi-country approach (see among others, Brunello et al. 2016). According to Model I, Panel A, exposure to reform has a positive and significant effect on education. The size of the effect (0.368) represents an increase of about 4.4 additional months of schooling. We find a comparable result in Panel B using years of compulsory education. For each

\footnotetext{
${ }^{13}$ This suggests that we should not be very concerned about weak instruments in our case; in any case, similar results were obtained using LIML estimators.
} 

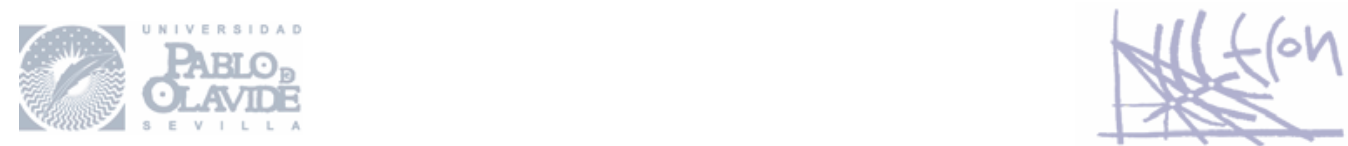

additional year of compulsory education, schooling raises on average 0.168 years, about 2 months. The results indicate that the reform dummy is a better instrument than years of compulsory education. In the sequel, we present the results corresponding to the reform dummy, although the Online Appendix provides the results with the other instrument.

Women and men are similarly affected by the reforms. Individuals who grew up in poor families when they were teenagers (Poor) are strongly affected by CSL with an increase of 0.496 years, about 6 months, while for the non-poor is only 0.302 years, about 3.6 months. Interestingly, for individuals who have at least one parent with secondary or higher education, reforms have no effect. The reason is that they would surely have continued in school, even in the absence of the reform. On the contrary, reforms have a strong impact on those who grew up in families with little education with an increase of 0.463 additional years, about 5.5 months.

In summary, individuals from disadvantaged families (poor or low educated) are the most affected. Without the reform, many of them would have probably dropped out earlier from school, since these families value less or cannot afford their children's education (Piopiunik, 2014).

\subsection{Main Equation}

Table 3 reports the results corresponding to Equation (1) and our three health measures in panels A, B and C, respectively. We also show OLS estimations.

The OLS estimates suggest that education has a positive but moderate effect on health. All of them are positive and statistically significant. With our first measure of health, estimated coefficients are around 0.02. Having one more year of education increases the probability of reporting good health by 2 percentage points, relative to a sample mean of 55\%. For the other two variables, effects are smaller. About 1.3-1.4 
percentage points for our second measure, relative to a sample mean of $77 \%$, and about 1 percentage point for the last one, relative to a sample mean of $67 \%$.

Table 3: Second Stage results

\begin{tabular}{|c|c|c|c|c|c|c|c|}
\hline & $\begin{array}{c}\text { I } \\
\text { All }\end{array}$ & $\begin{array}{c}\text { II } \\
\text { Men }\end{array}$ & $\begin{array}{c}\text { III } \\
\text { Women }\end{array}$ & $\begin{array}{c}\text { IV } \\
\text { Non poor }\end{array}$ & $\begin{array}{c}\text { V } \\
\text { Poor }\end{array}$ & $\begin{array}{c}\text { VI } \\
\text { Educated }\end{array}$ & $\begin{array}{c}\text { VII } \\
\text { Non } \\
\text { educated }\end{array}$ \\
\hline \multicolumn{8}{|c|}{ A. Dependent variable is good health reported } \\
\hline $\begin{array}{l}\text { OLS coeff. } \\
\text { years }\end{array}$ & $0.020 * * *$ & $0.018 * * *$ & $0.022 * * *$ & $0.020 * * *$ & $0.017 * * *$ & $0.024 * * *$ & $0.019 * * *$ \\
\hline schooling & $(0.001)$ & $(0.001)$ & $(0.001)$ & $(0.001)$ & $(0.001)$ & $(0.002)$ & $(0.001)$ \\
\hline $\begin{array}{l}\text { IV coeff. } \\
\text { years }\end{array}$ & 0.028 & -0.004 & 0.053 & 0.057 & 0.012 & 0.496 & 0.006 \\
\hline schooling & $(0.030)$ & $(0.039)$ & $(0.037)$ & $(0.050)$ & $(0.029)$ & $(0.857)$ & $(0.027)$ \\
\hline Observations & 45,767 & 21,172 & 24,595 & 28,237 & 17,530 & 11,162 & 34,605 \\
\hline \multicolumn{8}{|c|}{ B. Dependent variable is not limited in daily activities } \\
\hline $\begin{array}{l}\text { OLS coeff. } \\
\text { years }\end{array}$ & $0.013^{* * *}$ & $0.013 * * *$ & $0.013 * * *$ & $0.014^{* * *}$ & $0.013^{* * *}$ & $0.014 * * *$ & $0.014 * * *$ \\
\hline schooling & $(0.001)$ & $(0.001)$ & $(0.001)$ & $(0.001)$ & $(0.001)$ & $(0.001)$ & $(0.001)$ \\
\hline $\begin{array}{l}\text { IV coeff. } \\
\text { years }\end{array}$ & 0.012 & 0.022 & 0.004 & 0.018 & 0.009 & -0.173 & 0.012 \\
\hline schooling & $(0.026)$ & $(0.038)$ & $(0.032)$ & $(0.041)$ & $(0.035)$ & $(0.440)$ & $(0.022)$ \\
\hline Observations & 45,710 & 21,136 & 24,574 & 28,202 & 17,508 & 11,151 & 34,559 \\
\hline \multicolumn{8}{|c|}{ C. Dependent variable is no chronic illness } \\
\hline $\begin{array}{l}\text { OLS coeff. } \\
\text { years }\end{array}$ & $0.010 * * *$ & $0.009 * * *$ & $0.012 * * *$ & $0.011 * * *$ & $0.009 * * *$ & $0.012 * * *$ & $0.010 * * *$ \\
\hline schooling & $(0.001)$ & $(0.001)$ & $(0.001)$ & $(0.001)$ & $(0.001)$ & $(0.002)$ & $(0.001)$ \\
\hline $\begin{array}{l}\text { IV coeff. } \\
\text { years }\end{array}$ & 0.038 & -0.004 & $0.079 * *$ & 0.039 & 0.049 & 0.295 & 0.022 \\
\hline schooling & $(0.030)$ & $(0.038)$ & $(0.040)$ & $(0.049)$ & $(0.034)$ & $(0.507)$ & $(0.027)$ \\
\hline Observations & 45,728 & 21,150 & 24,578 & 28,216 & 17,512 & 11,154 & 34,574 \\
\hline
\end{tabular}

Notes: All models include as controls noncitizen, father_only, country-specific quadratic trends, cohort fixed effects, and country-specific survey effects. 

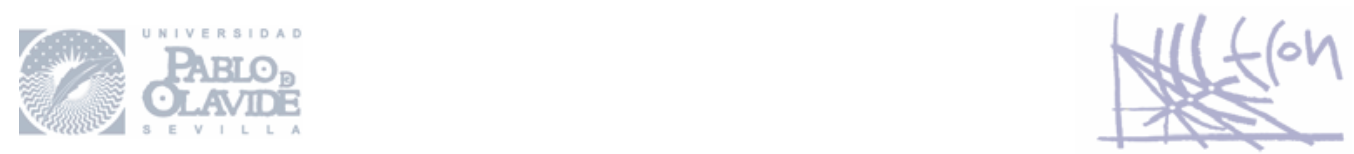

Our OLS estimates are similar in size to others in the literature. In particular, our OLS for self-reported good health is quite close to the 0.026 found by Silles (2009) for the UK. However, it is much lower than the one found by Oreopoulos $(2006,2008)$ for the same country, 0.065. Regarding no-chronic illness and not-limited our OLS are 0.01 and 0.013 respectively again comparable to those found by Silles (2009) for the UK (0.008 for each).

Our IV estimates are never statistically significant, except for the third measure of health in the sub-sample of women. ${ }^{14}$ However, as our IV estimates are less precisely estimated, we cannot rule out the possibility that education has a large effect on health outcomes. The 95\% confident intervals for our three measures (All individuals) are $[-0.030,0.086],[-0.038,0.062]$, and $[-0.022,0.097]$, respectively. In particular, the OLS estimates lie always within the corresponding confidence interval. ${ }^{15}$

\subsection{Alternative measures of education}

Our measure of education excludes individuals with twenty or more years of completed education since, according to Figure 1, education and health outcomes cease to be positively correlated for that range of values. We estimate again the model including individuals older than 19 years. This increases sample size by $5 \%$. Results are similar though, as expected, the instrument is now weaker (first-stage F statistic 22.49, compared to 28.27). See Table O4, Online Appendix.

We use next an alternative measure of education, the indicator variable that takes value one if the subject has completed at least secondary education (SE). This

\footnotetext{
${ }^{14}$ The 95\% confidence interval for the estimated coefficient is [0.0007, 0.1571].

15 Table O2, Online Appendix, shows the results using years of compulsory schooling as instrument.
} 
alternative variable could be a more appropriate proxy for educational achievement (learning) than the number of years at school.

Table 4: The measure of education is SE

\begin{tabular}{ccccccc}
\hline I & II & III & IV & V & VI & VII \\
All & Men & Women & Non Poor & Poor & Educated & Non educated \\
\hline
\end{tabular}

A. Dependent variable is good health reported

$\begin{array}{llcccccc}\text { OLS coefficient } & 0.117^{* * *} & 0.103^{* * *} & 0.130^{* * *} & 0.119 * * * & 0.109 * * * & 0.145^{* * *} & 0.114^{* * *} \\ & (0.005) & (0.008) & (0.007) & (0.007) & (0.007) & (0.013) & (0.005)\end{array}$

IV coefficient

$\begin{array}{ccccccc}0.388 & -0.131 & 0.553 & 0.618 & 0.284 & 4.863 & 0.094 \\ (0.438) & (0.956) & (0.431) & (0.603) & (0.649) & (10.528) & (0.416)\end{array}$

B. Dependent variable is not limited in daily activities

$\begin{array}{lllllll}(0.004) & (0.006) & (0.007) & (0.006) & (0.006) & (0.015) & (0.005)\end{array}$

IV coefficient

$\begin{array}{ccccccc}0.167 & 0.525 & 0.044 & 0.191 & 0.216 & -1.834 & 0.185 \\ (0.359) & (1.002) & (0.324) & (0.455) & (0.765) & (4.713) & (0.343)\end{array}$

C. Dependent variable is no chronic

$\begin{array}{lccccccc}\text { OLS coefficient } & 0.063^{* * *} & 0.052^{* * *} & 0.073^{* * *} & 0.068^{* * *} & 0.054^{* * *} & 0.082^{* * *} & 0.062^{* * *} \\ & (0.006) & (0.009) & (0.007) & (0.007) & (0.008) & (0.016) & (0.006) \\ \text { IV coefficient } & & & & & & & \\ & 0.513 & -0.104 & 0.802^{*} & 0.425 & 1.092 & 3.079 & 0.335 \\ & (0.458) & (0.887) & (0.474) & (0.558) & (0.907) & (6.737) & (0.441)\end{array}$

First-Stage

\begin{tabular}{lccccccc} 
1st stage & $0.027 * * *$ & 0.015 & $0.036^{* * *}$ & $0.028^{* *}$ & 0.021 & 0.007 & $0.030^{* * *}$ \\
coefficient & $(0.009)$ & $(0.011)$ & $(0.012)$ & $(0.013)$ & $(0.015)$ & $(0.014)$ & $(0.010)$ \\
& & & & & & & \\
1st stage F-test & 9.115 & 1.934 & 9.207 & 4.823 & 2.067 & 0.237 & 9.171 \\
P-value & 0.003 & 0.166 & 0.003 & 0.030 & 0.153 & 0.627 & 0.003 \\
& & & & & \\
Observations & 45,767 & 21,172 & 24,595 & 28,237 & 17,530 & 11,162 & 34,605 \\
\hline \multicolumn{7}{l}{ Robust standard errors in parentheses; $* * * \mathrm{p}<0.01, * * \mathrm{p}<0.05, * \mathrm{p}<0.1$}
\end{tabular}

Robust standard errors in parentheses; ${ }^{* * *} \mathrm{p}<0.01,{ }^{* *} \mathrm{p}<0.05,{ }^{*} \mathrm{p}<0.1$

Table 4 shows that reforms have a positive effect on completing at least secondary education, but the instrument is weaker than our main measure of education (see Section 5 for a deeper discussion on this alternative measure of education). In any 

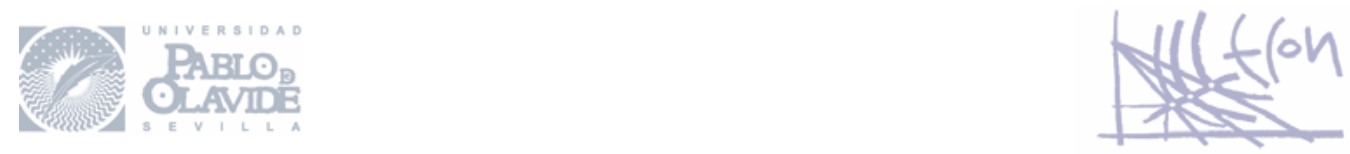

case, again we see that finishing secondary education does not seem to have an effect on any of our health measures.

Finally, we perform several checks to show that our results are robust to different changes in our main specification (first stage), measure of education, selection of countries, using a different dataset (European Social Survey), window size, excluding individuals who are not the potential target of the reforms and performing a placebo test. Results, which can be found in the Online Appendix, are in line with the main findings in tables 2 and 3 above.

\section{Discussion}

In this section we explore possible drivers of our findings as the characteristics of our sample, the adequacy of the timing of the reforms and the role of education quality.

\subsection{Individuals' sample age}

An important difference between our work and those who find a causal effect of education on health outcomes is the average sample age. In Brunello et al. (2016), average age is 65.5, while in Crespo et al. (2014) is 58.13. In our EU-SILC sample average age is 53.2, and in the ESS sample is 54.5.

According to the cumulative (dis)advantages hypothesis, health differences between individuals of different educational levels are only present at a relatively high age. Lower-educated individuals are more exposed and vulnerable to the adverse consequences of health risks due to their lack of both monetary and information resources. While public health systems may limit these differences and reduce selection effects due to premature mortality, differences tend to appear later in life. Leopold and Leopold (2018) report evidence in favor of this hypothesis using data for Germany. This could explain differences between previous work and our results. 

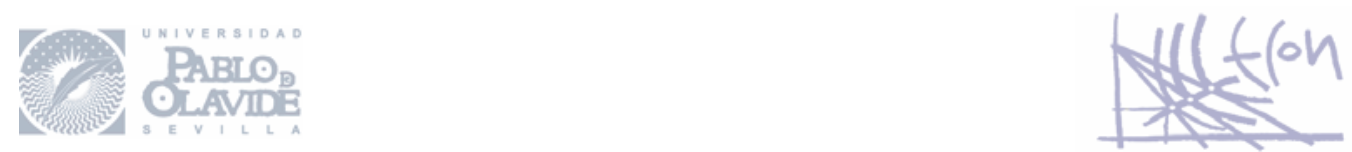

Alternatively, it could be a selection problem. Suppose subjects differ according to pre-existing unobservable conditions (think, for instance, of child health). Assume also that for education to have a causal effect on adult health, pre-existing conditions must be good enough. We could model this by assuming that child health and education are complements in the production of adult health. Since our sample combines individuals with different pre-existing conditions, the existence of a causal effect of education on health depends on the proportions of individuals with different conditions. If mortality is greater among individuals with poor pre-existing conditions, the older the sample the more likely we are to find a causal effect of education on health. As the average age of the sample increases, individuals with poor pre-existing conditions will be less represented in the sample. In our data, we lack appropriate controls for preexisting conditions. However, our two measures of family background (poor/non-poor and non-educated/educated families) could be seen as proxies of those conditions. We have some evidence on this in our data since, as can be seen in Table 3, the association between education and self-reported health as measured by our OLS coefficients is stronger for individuals from non-poor families (0.020), than for those raised in poor families (0.017). In the same line, the coefficient for those from educated families (0.024) is higher than for those from families with little education (0.019). ${ }^{16}$

\subsection{Reforms' characteristics}

All our reforms affect subjects in secondary education. ${ }^{17}$ Our result only says that interventions that increase education at this particular level have no impact on health outcomes. This does not mean that any intervention is useless. James Heckman has

\footnotetext{
${ }^{16}$ The first difference is not significant $(\mathrm{p}=0.137)$, but the second one it is $(\mathrm{p}=0.016)$.

${ }^{17}$ The increase in the school leaving age is from 14 to 15 in five reforms, from 14 to 16 in two, from 13 to 15 in one, from 14 to 16 in one, from 12 to 13 in one, from 11 to 14 in one, and from 10 to 12 in one.
} 


\section{dew}

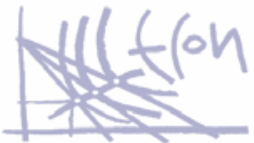

repeatedly stressed that the best moment to intervene is in the early stages of education, particularly for disadvantaged children and their families. ${ }^{18}$ In this sense, all the reforms we consider can be seen as late interventions, when individuals are already too old for the reform to have an effect, particularly those with a low SES.

Another possibility is that for reforms to be successful, they must have an effect not only on increasing years of schooling, but also on the probability that subjects complete an educational stage. We check this by focusing on the first stage results when the education measure is SE (completing at least secondary education). Table 5, panels A and B, shows this. In Panel A, we include all individuals, while in Panel B we remove those with completed tertiary education.

Reforms have always a positive effect on the probability of completing secondary studies, but the effect is weaker than with years of education. The F-statistics are always below 10. If we were to use having secondary education as our measure of education to explain health outcomes, we would run into a problem of weak instruments. In fact, we find no effect at all for men, poor individuals, and individuals from educated families. There is an effect for women, for the non-poor, and for individuals from non-educated families. The strongest effect we get is the one for women (0.036), which means that women affected by the reform are 3.6 percentage points more likely to finish secondary education. This effect is not negligible, since 59.8 percent of the women in the sample have completed secondary education. Results are very similar after removing individuals with tertiary education (Panel B), although now the weak instruments problem gets worse. In summary, if having secondary education is

\footnotetext{
${ }^{18}$ Cunha and Heckman (2007) propose a technology of skill formation characterized by selfproductivity, dynamic complementarity, and skill multipliers to explain the larger impact of early interventions found in the literature. See https:/heckmanequation.org/
} 

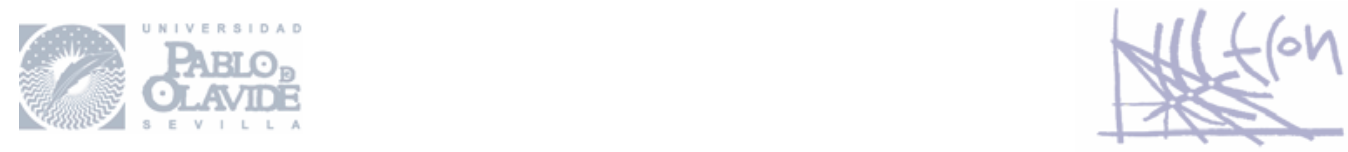

a better measure of educational attainment than years of education, we can hardly identify the effect of education because of a weak instruments problem.

Alternatively, it could be that increases in tertiary education are those that have a positive effect on health. Buckles et al. (2016) use US data finding that college education has a positive effect on reducing mortality, mostly because of a reduction in deaths due to cancer and heart disease. On the contrary, Janke et al. (2018), consider an expansion of college education in the UK, but only find a reduction in the prevalence of diabetes. We check if CSL have any effect on the probability of getting tertiary education, by estimating a model where the endogenous variable is a dummy that takes value one when subjects have tertiary education. The main explanatory variable is the reform dummy and we include the same covariates as in Table 3. Results are in Table 5, Panel C.

The positive effect of reforms on education that we observed in Table 3 does not seem to occur with tertiary education. This would mean that indeed very marginal individuals are affected by the reforms. They are required by law to stay a bit longer in secondary education and some complete this level, but most of them do not continue beyond. If the education that matters to improve health is tertiary education, our reforms cannot identify that effect.

Another reason why we do not find an effect has to do with a LATE interpretation of our results. Since we use CSL, we can only identify an effect for those individuals affected by the reforms. Then, previous works that use earlier reforms are more likely to find an effect than those that use reforms that are more recent. To fix ideas, think of two changes in British compulsory schooling laws. The first was implemented in 1947, raising school leaving age from 14 to 15 . The second one was introduced in 1972, raising it from 15 to 16. As Clark and Royer (2013) explain, the 

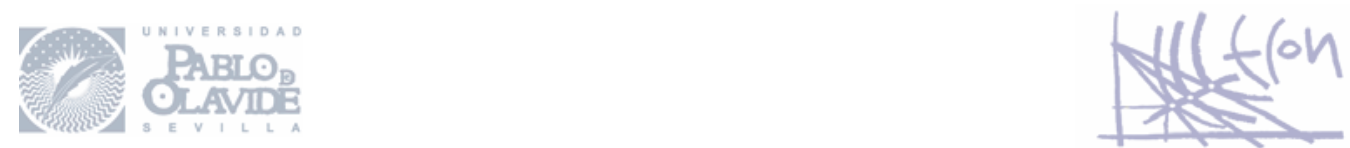

first one affected $50 \%$ of individuals in the relevant cohorts, and the second one about $25 \%$. The difference in effect size is due to the secular positive trend in education. In addition, the type of individuals affected is potentially very different. In 1947, it is likely that among the individuals affected there were many people of great ability who would have left school without the reform. In 1972, this is already less likely. Our argument is that the more recent are the reforms, the worse is the average ability of affected individuals. To sum up, the most skilled individuals are not among those affected by the most recent reforms. Then, if the causal effect of education on health is mediated by ability or skill, we should not observe an effect for these marginal subjects when we use relatively recent reforms. Note that this has nothing to do with education quality.

A final related argument could explain why studies using early 20th century reforms find an impact of education on health whereas we, using later reforms, do not. Those early reforms may have reduced individuals' exposure to dangerous factory or tough agriculture jobs. By attending secondary education, individuals at the beginning of the 20th century improved their access to white-collar jobs, but not so much in later reforms. By considering later reforms, we do not observe these health gains. ${ }^{19}$ In addition, according to Malamud et al. (2018), the unclear association between education and health might be due to changes in the occupation structure. Even if education reduces individuals' exposure to manufacture and agriculture jobs and increase their chances to get professional jobs this might not always translate into better working conditions. That could be the case if, for instance, these white-collar occupations are associated with more stress than other unskilled jobs or they are more likely to be

\footnotetext{
${ }^{19}$ See also Galama et al. (2018) or Clark and Royer (2013) for a similar argument.
} 
sedentary occupations, which could be detrimental for health (see Böckerman et al., 2008). 
Table 5: Effect of reforms on finishing secondary and tertiary education

\begin{tabular}{|c|c|c|c|c|c|c|c|}
\hline & $\begin{array}{c}\text { I } \\
\text { All }\end{array}$ & $\begin{array}{c}\text { II } \\
\text { Men }\end{array}$ & $\begin{array}{c}\text { III } \\
\text { Women }\end{array}$ & $\begin{array}{c}\text { IV } \\
\text { Non poor }\end{array}$ & $\begin{array}{c}\mathrm{V} \\
\text { Poor }\end{array}$ & $\begin{array}{c}\text { VI } \\
\text { Educated }\end{array}$ & $\begin{array}{c}\text { VII } \\
\text { Non educated }\end{array}$ \\
\hline \multicolumn{8}{|c|}{ A. Dependent variable is having secondary education } \\
\hline Reform dummy & $\begin{array}{c}0.027 * * * \\
(0.009)\end{array}$ & $\begin{array}{c}0.015 \\
(0.011)\end{array}$ & $\begin{array}{c}0.036 * * * \\
(0.012)\end{array}$ & $\begin{array}{c}0.028 * * \\
(0.013)\end{array}$ & $\begin{array}{c}0.021 \\
(0.015)\end{array}$ & $\begin{array}{c}0.007 \\
(0.014)\end{array}$ & $\begin{array}{c}0.030 * * * \\
(0.010)\end{array}$ \\
\hline 1st stage F-test & 9.115 & 1.934 & 9.207 & 4.823 & 2.067 & 0.237 & 9.171 \\
\hline P-value & 0.003 & 0.166 & 0.003 & 0.030 & 0.153 & 0.627 & 0.003 \\
\hline Observations & 45,767 & 21,172 & 24,595 & 28,237 & 17,530 & 11,162 & 34,605 \\
\hline \multicolumn{8}{|c|}{ B. Dependent variable is finished secondary education, excluding those with tertiary education } \\
\hline Reform dummy & $\begin{array}{c}0.023^{* *} \\
(0.010)\end{array}$ & $\begin{array}{c}0.005 \\
(0.013)\end{array}$ & $\begin{array}{c}0.039 * * * \\
(0.013)\end{array}$ & $\begin{array}{c}0.023 \\
(0.016)\end{array}$ & $\begin{array}{c}0.022 \\
(0.015)\end{array}$ & $\begin{array}{c}0.011 \\
(0.020)\end{array}$ & $\begin{array}{c}0.025^{* *} \\
(0.011)\end{array}$ \\
\hline 1st stage F-test & 5.376 & 0.123 & 8.632 & 2.228 & 2.208 & 0.318 & 4.912 \\
\hline P-value & 0.022 & 0.727 & 0.004 & 0.138 & 0.139 & 0.573 & 0.028 \\
\hline Observations & 40,757 & 18,808 & 21,949 & 24,229 & 16,528 & 8,318 & 32,439 \\
\hline \multicolumn{8}{|c|}{ C. Dependent variable is having tertiary education } \\
\hline Reform dummy & $\begin{array}{c}0.002 \\
(0.006)\end{array}$ & $\begin{array}{c}0.008 \\
(0.009)\end{array}$ & $\begin{array}{l}-0.003 \\
(0.007)\end{array}$ & $\begin{array}{c}0.003 \\
(0.008)\end{array}$ & $\begin{array}{c}0.004 \\
(0.010)\end{array}$ & $\begin{array}{l}-0.014 \\
(0.019)\end{array}$ & $\begin{array}{c}0.009 \\
(0.006)\end{array}$ \\
\hline 1st stage F-test & 0.098 & 0.824 & 0.248 & 0.101 & 0.202 & 0.585 & 2.420 \\
\hline P-value & 0.755 & 0.366 & 0.619 & 0.751 & 0.654 & 0.446 & 0.122 \\
\hline Observations & 45,767 & 21,172 & 24,595 & 28,237 & 17,530 & 11,162 & 34,605 \\
\hline
\end{tabular}

Notes: In panels A and B the endogenous variable is a dummy that takes value one if the individual has secondary education. In panel B we exclude all individuals with tertiary education. In panel $\mathrm{C}$ the endogenous variable is a dummy that takes value one if the individual has tertiary education. Window of 7 years, errors clustered at the country cohort-of-birth level. The F-test corresponds to the null hypothesis that the coefficient of the reform dummy is zero. 


\subsection{Education quality}

Another potential channel has to do with the quantity versus quality debate. ${ }^{20}$ The only information we have about reforms is that they oblige adolescents to continue in school one or more additional years. If this additional education is low quality, its effect may be weak. One way to check this is to use per capita spending data in education as a quality proxy. For the four Southern European countries, average public expenditure in education was 3.04\% of GDP, while for the default category was $5.09 \% .{ }^{21}$ We then estimate our model separately, first for the group of South European countries (Greece, Italy, Malta, Portugal), and then for the rest of countries. The results are in Table 6.

Reforms have a much stronger effect in the Southern countries. This may be because the countries in the South are those where the years of compulsory education increase the most (see Table 1 ). ${ }^{22}$ However, if we divide the first-stage coefficients by the weighted averages above, we still get a bigger effect of reforms in the South. ${ }^{23}$ In other words, a disproportionate part of the exogenous variation in education produced by the instrument happens in the South. This could be a problem if either of two conditions meet: 1) the quality of the additional education is lower in the South; ii) there

20 For instance, Pischke and Von Wachter (2008) provide evidence for Germany that reforms increase time at school, but not the quality of education provided. Bold et al. (2017) for evidence on the relationship between quality of education and returns to it. Recently, Glymour and Manly (2018) also proposes a similar explanation for the mixed findings across CSL studies on education and health.

${ }^{21}$ The UNESCO database has data of public expenditure in education as a percentage of GDP for some of the countries we use for the years 1970-80. Country data: Greece 1.42, Portugal 2.63, Italy 3.68, Malta 4.46, France 3.96, Austria 4.79, Ireland 4.82, UK 5.61, Netherlands 6.27. UNESCO has no data for those years in ex-communist countries (http://data.uis.unesco.org/index.aspx?queryid=181\#).

${ }^{22}$ The first-stage coefficient is 1.13 in the South, compared to just 0.26 in the rest. The weighted average of the increase in compulsory education is 2.8 years in the South, and only 1.1 in the rest. Weights are country sample sizes.

${ }^{23}$ For every additional year of compulsory education, our measure of education raises by 0.40 years in the South (1.13/2.8), and only 0.24 years in the other countries $(0.26 / 1.1)$. 

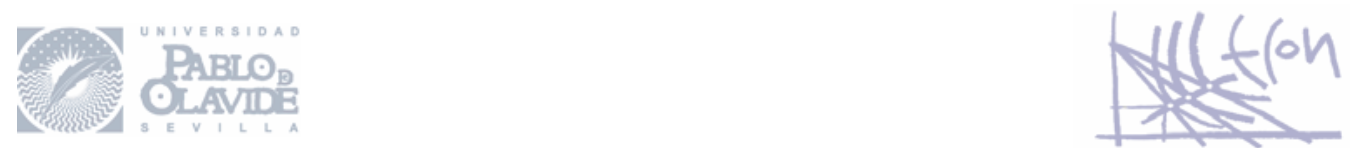

is less health inequality among people with different educational levels. The first condition gets support from the data on public expenditure in education described above. We add years of education, but this additional education is of low quality, so we should not expect much impact on health. The second argument gets some support in Table 4. We see that, for our three measures of health, the correlation between education and health is much lower in the South. We have an instrument that has a bigger impact on countries with a low quality of education, where individuals with different educational levels have more similar health outcomes.

Table 6: South vs North

\begin{tabular}{|c|c|c|}
\hline & Southern Europe & Rest of countries \\
\hline \multicolumn{3}{|c|}{ A. Dependent variable is good health reported } \\
\hline $\begin{array}{l}\text { OLS coefficient of } \\
\text { education measure }\end{array}$ & $\begin{array}{c}0.016^{* * *} \\
(0.001)\end{array}$ & $\begin{array}{c}0.024^{* * *} \\
(0.001)\end{array}$ \\
\hline $\begin{array}{l}\text { IV coefficient of } \\
\text { education measure }\end{array}$ & $\begin{array}{l}-0.001 \\
(0.029)\end{array}$ & $\begin{array}{c}0.034 \\
(0.053)\end{array}$ \\
\hline \multicolumn{3}{|c|}{$\begin{array}{l}\text { B. Dependent variable is not limited in daily } \\
\text { activities }\end{array}$} \\
\hline $\begin{array}{l}\text { OLS coefficient of } \\
\text { education measure }\end{array}$ & $\begin{array}{c}0.010^{* * *} \\
(0.001)\end{array}$ & $\begin{array}{c}0.017 * * * \\
(0.001)\end{array}$ \\
\hline $\begin{array}{l}\text { IV coefficient of } \\
\text { education measure }\end{array}$ & $\begin{array}{c}0.010 \\
(0.021)\end{array}$ & $\begin{array}{c}0.036 \\
(0.044)\end{array}$ \\
\hline \multicolumn{3}{|c|}{ C. Dependent variable is no chronic } \\
\hline $\begin{array}{l}\text { OLS coefficient of } \\
\text { education measure }\end{array}$ & $\begin{array}{c}0.007 * * * \\
(0.001)\end{array}$ & $\begin{array}{c}0.015^{* * *} \\
(0.001)\end{array}$ \\
\hline $\begin{array}{l}\text { IV coefficient of } \\
\text { education measure }\end{array}$ & $\begin{array}{c}0.021 \\
(0.028)\end{array}$ & $\begin{array}{c}0.066 \\
(0.048)\end{array}$ \\
\hline First-Stage coeff. & $\begin{array}{c}1.131^{* * *} \\
(0.235)\end{array}$ & $\begin{array}{c}0.259 * * * \\
(0.059)\end{array}$ \\
\hline
\end{tabular}




\begin{tabular}{lcc}
\hline 1st stage F-test & 23.123 & 19.035 \\
P-value & 0.000 & 0.000
\end{tabular}

Observations $17,492 \quad 28,275$

Notes: Southern Europe includes Greece, Italy, Malta, and Portugal. Rest of Europe includes all other countries. The set of controls is the same as in tables 2 and 3.

\subsection{Is education useless?}

We find no causal effect of education on any of our health outcomes. However, this does not mean that education is useless. EU-SILC contains information on household income and education has been repeatedly found to have a causal effect on income. We estimate again our model described in equations (1) and (2), replacing health outcomes with an income measure. In particular, we focus on total disposable household income. ${ }^{24}$ We begin by estimating in Table 7 an OLS model corresponding for each group in tables 2-3.

Table 7: Effect of years of education on household income

\begin{tabular}{|c|c|c|c|c|c|c|c|}
\hline & $\begin{array}{c}\text { I } \\
\text { All }\end{array}$ & $\begin{array}{c}\text { II } \\
\text { Men }\end{array}$ & $\begin{array}{c}\text { III } \\
\text { Women }\end{array}$ & $\begin{array}{c}\text { IV } \\
\text { Non poor }\end{array}$ & $\begin{array}{c}\mathrm{V} \\
\text { Poor }\end{array}$ & $\begin{array}{c}\text { VI } \\
\text { Educated }\end{array}$ & $\begin{array}{c}\text { VII } \\
\text { Non } \\
\text { educated }\end{array}$ \\
\hline \multicolumn{8}{|c|}{ Dependent variable is household income (hy022) } \\
\hline $\begin{array}{l}\text { OLS coeff. } \\
\text { years } \\
\text { schooling }\end{array}$ & $\begin{array}{c}0.067 * * * \\
(0.003)\end{array}$ & $\begin{array}{c}0.064^{* * *} \\
(0.003)\end{array}$ & $\begin{array}{c}0.068 * * * \\
(0.003)\end{array}$ & $\begin{array}{c}0.068 * * * \\
(0.003)\end{array}$ & $\begin{array}{c}0.063 * * * \\
(0.003)\end{array}$ & $\begin{array}{c}0.078 * * * \\
(0.004)\end{array}$ & $\begin{array}{r}0.063^{* * * *} \\
(0.003)\end{array}$ \\
\hline $\begin{array}{l}\text { IV coeff. } \\
\text { years } \\
\text { schooling }\end{array}$ & $\begin{array}{c}0.203^{* * *} \\
(0.073)\end{array}$ & $\begin{array}{l}0.176^{*} \\
(0.090)\end{array}$ & $0.224 * * *$ & $(0.096)$ & $0.260 * * *$ & $(1.934)$ & $(0.064)$ \\
\hline Observations & 44,479 & 20,562 & 23,917 & 27,564 & 16,915 & 10,922 & 33,557 \\
\hline
\end{tabular}

Notes: Household income is measured with variable hy022. All models include as controls noncitizen, father_only, country-specific quadratic trends, cohort fixed effects, and countryspecific survey effects.

\footnotetext{
${ }^{24}$ We choose the variable hy022, total disposable household income before social transfers other than old-age and survivor benefits. Other measures of household income in EU-SILC, as hy020 (total disposable household income) or $h x 090$ (equivalized disposable income) include all redistributive public transfers.
} 
One additional year of education is associated with an increase in disposable income of about 6-7 percentage points. The correlation is similar for the different subgroups. Next, we estimate an IV model, using the reform dummy as instrument. We do not find an effect for the non-poor and for those from educated families. In the latter case, the cause is again that the instrument has no bite. We find a significant and positive effect with all individuals, for the poor, and for those from low educated families. For all these groups, education seems to have a positive and sizable effect on disposable household income. It is interesting to mention that in all cases but one (poor individuals), the OLS coefficient lies within the 95\% confidence interval of the corresponding IV estimate. In the case of poor individuals, the whole $95 \%$ confidence interval is shifted to the right of the IV estimate. This is in stark contrast with our results using health measures, where the IV estimates are never significant, while OLS always are.

Given that we find a mostly positive effect of education on income, why we do not find an effect on health? One reason could be that, as Clark and Royer (2013) suggest, health effects of income need not always be positive. For instance, higher income individuals may spend more income on alcohol and cigarettes. ${ }^{25}$ Furthermore, income effects on health might be positive but small. ${ }^{26}$ Another reason can be the existence of a universal public health service, which is the case of all European

\footnotetext{
${ }^{25}$ See Clark and Royer (2013) or Davies et al. (2018) for evidence on the impact of education on alcohol consumption and Gilman et al. (2008), Reinhold and Jürges (2010) or Malamud et al. (2018) for evidence on its impact on smoking behavior.

${ }^{26}$ Evans and Moore (2011) or more recently Cesarini et al. (2016), Muris (2017) or Janke et al. (2018) provide empirical support for this argument.
} 


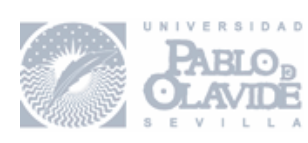

countries. ${ }^{27}$ This is somewhat related with our discussion on the average age in our sample. When individuals are relatively young, public health services can attenuate health differences between rich and poor individuals. As individuals get old, medical conditions become worse and it is more difficult for public health services to compensate for these differences. Again, this may be a reason why some previous works that use an older sample find an effect of education on health.

\section{Conclusions}

We study the causal effect of education on different health outcomes, using data from the 2005 and 2011 cross sections of EU-SILC. Our identification strategy exploits exogenous variation from CSL in twelve European countries. We do not find a positive effect on any of the three health measures we have. We also study if there may be an effect for specific groups by sex, parental education, or economic situation of the family. Again, we do not find any effect for any of these different groups. Our negative result is robust to a number of alternative specifications.

We discuss different explanations for our results. i) Consistently with the cumulative (dis)advantages hypothesis, our sample could be too young to observe the potential positive benefits of education. ii) The exogenous variation we exploit occurs at the level of secondary education. We cannot discard that additional schooling at other levels can have a protective effect of health. iii) A large part of the increase in education happens in countries where education quality was not very good at the time of reforms. Forcing young people to spend more time in a school that gives them relatively lowquality education may not be enough to reflect on better health when they grow up.

\footnotetext{
${ }^{27}$ Indeed, several authors have used also this argument to justify differences in results for USA versus European countries (see Galama et al. 2018 or Meghir et al. 2018 among others).
} 


\section{References}

Albouy, V., Lequien, L. (2009): “Does compulsory education lower mortality?" Journal of Health Economics 28, 1, 155-168.

Arendt, J. (2005): "Does education cause better health? A panel data analysis using school reform for identification,” Economics of Education Review 24, 149-160.

Böckerman, P., Johansson, E. Jousilahti, P., Uutela, A. (2008): "The physical strenuousness of work is slightly associated with an upward trend in the BMI," Social Science and Medicine 66, 1346-55.

Bold, T., Filmer, D., Martin, G., Molina, E., Stacy, B., Rockmore, C. (2017): "Enrollment without learning: Teacher effort, knowledge, and skill in primary schools in Africa,” Journal of Economic Perspectives 31(4), 185-204.

Brunello, G., Fabbri, D., Fort, M. (2013): “The Causal Effect of Education on Body Mass: Evidence from Europe,” Journal of Labor Economics 31, 1, 195-223.

Brunello, G., Fort, M., Schneeweiss, N., Winter-Ebmer, R. (2016): "The causal effect of education on health,” Health Economics 25, 3, 314-36.

Buckles, K., Hagemann, A., Malamud, O., Morrill, M., Wozniak, A. (2016): “The effect of college education on mortality,” Journal of Health Economics 50, 99-114.

Cesarini, D., Lindqvist E. Östling R., Wallace, B. (2016): "Wealth, health, and child development: evidence from administrative data on Swedish lottery players" The Quarterly Journal of Economics 131, 2, 687-738.

Clark, D., Royer, H. (2013): “The Effect of Education on Adult Mortality and Health: Evidence from Britain,” American Economic Review 103, 6, 2087-2120.

Courtin, E., Nafilyan, V., Avendano, M., Meneton, P., Berkman, L., Goldberg, M., Zins, M., Dowd, J. (2019): "Longer schooling but not better off? A quasi-experimental study of the effect of compulsory schooling on biomarkers in France," Social Science \& Medicine 220, 379-386.

Crespo, L., López-Noval, B., Mira, P. (2014): “Compulsory schooling, education, depression and memory: New evidence from SHARELIFE,” Economics of Education Review 43, 36-46.

Cunha, F., Heckman, J. (2007): “The technology of skill formation”, American Economic Review, 97, 2, 31-47.

Cutler, D., Lleras-Muney, A. (2006): "Education and health: Evaluating Theories and Evidence,” NBER WP 12352. 
Cutler, D., Lleras-Muney, A. (2012): "Education and health: Insights from international comparisons,” NBER WP 17738.

Davies, N., Dickson, M., Smith, G., Van den Berg, G., Windmeijer, F. (2018) “The causal effects of education on health, mortality, cognition, well-being, and income in the UK Biobank,” Nature and Human Behavior 2(2): 117-125.

Delaruelle, K., Buffel, V., Bracke, P. (2015): "Educational expansion and the education gradient in health: A hierarchical age-period-cohort analysis," Social Science \& Medicine 145, 79-88.

Eide, E., Showalter, M. (2011): "Estimating the relation between health and education: What do we know and what do we need to know?" Economics of Education Review 30, 778-791.

Evans, W., Moore, T. (2011): “The Short-Term Mortality Consequences of Income Receipt,” Journal of Public Economics 95, 11-12, 1410-1424.

Fischer, M., Karlsson, M., Nilsson, T. (2013): "Effects of compulsory schooling on mortality: Evidence from Sweden" International Journal of Environmental Research and Public Health 10, 3596-3618.

Fletcher, J. (2015): "New evidence of the effects of education on health in the US: Compulsory schooling laws revisited,” Social Science \& Medicine 127, 101-107.

Galama, T., Lleras-Muney, A., van Kippersluis, H. (2018): “The effect of education on health and mortality: A review of experimental and quasi-experimental evidence," Oxford Research Encyclopedia of Economics and Finance, forthcoming.

Gathmann, C., Jürges, H., Reinhold, S. (2015): “Compulsory Schooling Reforms, Education and Mortality in Twentieth Century Europe," Social Science \& Medicine 127, 74-82.

Gilman, S., Martin, L. Abrams, D., Kawachi, I., Kubzansky, L., Loucks, E., Rende, R., Rudd, R., Buka, S. (2008): "Educational attainment and cigarette smoking: a causal association?” International Journal of Epidemiology 37(3): 615-624.

Glymour, M., Manly, J. (2018): “Compulsory Schooling Laws as quasi-experiments for the health effects of education: Reconsidering mechanisms to understand inconsistent results,” Social Science \& Medicine 214, 67-69.

Grossman, M. (2006): "Education and Nonmarket Outcomes.” Chapter 10 in Hanushek, Welch, F. (eds.), Handbook of the Economics of Education, Vol. 1, Amsterdam: Elsevier, 577-633.

Grossman, M. (2008): “The Relationship between Health and Schooling,” Eastern Economic Journal 34 (3), 281-292. 
Hamad, R., Elser, H., Tran, D., Rehkopf, D., Goodman, S. (2018): "How and why studies disagree about the effects of education on health: A systematic review and metaanalysis of studies of compulsory schooling laws," Social Science \& Medicine 212, 168-178.

Haveman, R., Wolfe, B. (1995): “The Determinants of Children's Attainments: A Review of Methods and Findings”, Journal of Economic Literature 33, 1829-1878.

Janke, K., Johnston, D., Propper, C., Shields, M. (2018): “The Causal Effect of Education on Chronic Health Conditions,” IZA DP 11353.

Jürges, H., Kruk, E., Reinhold, S. (2013): "The effect of compulsory schooling on health-evidence from biomarkers," Journal of Population Economics 26(2), 645672.

Kemptner, D., Jürges, H., Reinhold, S. (2011): "Changes in compulsory schooling and the causal effect of education on health: Evidence from Germany," Journal of Health Economics 30, 340-354.

Lleras-Muney, A. (2005): "The relationship between education and adult mortality in the United States,” Review of Economic Studies 72, 189-221.

Leopold, L., Leopold, T. (2018): "Education and Health across Lives and Cohorts: A Study of Cumulative (Dis)advantage and Its Rising Importance in Germany,” Journal of Health and Social Behavior 59(1), 94-112.

Lochner, L. (2011): "Non-production benefits of education: Crime, health, and good citizenship.” Chapter 2 in Hanushek, E., Machin, S., Woessmann, L. (eds.), Handbook of the Economics of Education, Vol. 4, Amsterdam: Elsevier, 183-282.

Malamud, O., Mitrut, A., Pop-Eleches, C. (2018): “The Effect of Education on Mortality and Health: Evidence from a Schooling Expansion in Romania” NBER Working Paper 24341.

Mazzona, F. (2014): "The long-lasting effects of education on old age: Evidence of gender differences,” Social Science \& Medicine 101, 129-138.

Meghir, C., Palme, M., Simeonova, E. (2018) "Education and mortality: Evidence from a social experiment,” American Economic Journal: Applied Economics, 10(2), 234256.

Mocan, N., Pogorelova, L. (2017): "Compulsory schooling laws and formation of beliefs: Education, religion and superstition,” Journal of Economic Behavior and Organization, 142, 509-539.

Muris, C. (2017): "Estimation in the fixed-effects ordered logit model” The Review of Economics and Statistics, 99(3): 465-477 

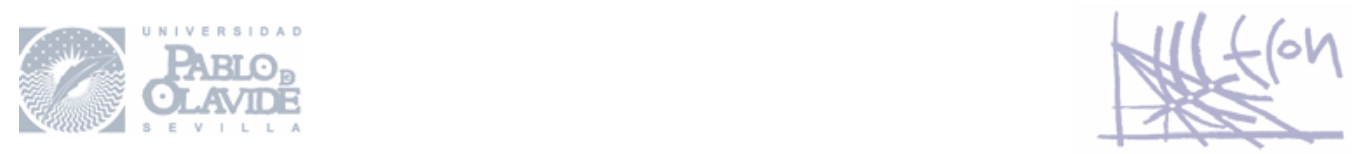

Oreopoulos, P. (2006): "Estimating average and local average treatment effects of education when compulsory schooling laws really matter," American Economic Review 96, 1, 152-175.

Oreopoulos, P. (2008): "Estimating Average and Local Average Treatment Effects of Education when Compulsory Schooling Laws Really Matter: Corrigendum”, University of British Columbia WP.

Piopiunik, M. (2014): "Intergenerational Transmission of Education and Mediating Channels: Evidence from a Compulsory Schooling Reform in Germany," Scandinavian Journal of Economics 116(3), 878-907

Pischke, J. S., Von Wachter, T. (2008): "Zero returns to compulsory schooling in Germany: Evidence and interpretation,” Review of Economics and Statistics, 90(3), 592- 598 .

Powdthavee, N. (2010): "Does Education Reduce the Risk of Hypertension? Estimating the Biomarker Effect of Compulsory Schooling in England", Journal of Human Capital, 4(2), 173-202.

Reinhold, S., Jürges, H. (2010): "Secondary school fees and the causal effect of schooling on health behavior” Health Economics, 19, 994-1001.

Silles, M. (2009): "The causal effect of education on health: Evidence from the United Kingdom,” Economics of Education Review 28, 122-128.

Stephens, M., Yang, D-Y. (2014): "Compulsory Education and the Benefits of Schooling,” American Economic Review 104, 6, 1777-1792.

Van Kippersluis, H., O'Donnell, O., Van Doorslaer, E. (2011): “Long Run Returns to Education: Does Schooling Lead to an Extended Old Age?” Journal of Human Resources 46, 4, 695-721.

Wolff, P., Montaigne, F., Rojas González, G. (2010): "Investing in statistics: EUSILC,” Chapter 2 in A. B. Atkinson and E. Marlier (eds.), Income and Living Conditions in Europe. Luxembourg: Eurostat, 38-55. 


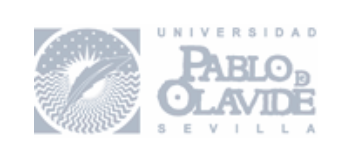

\section{ONLINE APPENDIX}

\section{Education and adult health: Is there a causal effect?}

\section{A. List of variables}

\section{Variables from EU-SILC}

Good health: A dummy variable that takes value 1 if the individual reports to have either good or very good health (ph010 is either 1 or 2). Individuals are asked, "How is your health in general?” Possible answers are: very good, good, fair, bad, and very bad.

Not limited: A dummy variable that takes value 1 if the individual reports to be not limited in daily life $($ ph030 $=3)$. Individuals are asked, "For at least the last 6 months, to what extent have you been limited because of a health problem in activities people usually do?” Possible answers are: not limited, limited, and very limited.

No chronic: A dummy variable that takes value 1 if the individual reports not to have a chronic condition (ph020 = 2). Individuals are asked, "Do you have any longstanding illness or health problem?” Possible answers are: yes, no.

Years of education (years_educ): We construct this variable using the year when the highest level of education was attained (pe030), birth year (pb140) and school entry age in each country. First, we calculate pe030-pb140-entry age. Second, we eliminate all individuals for which this number is either negative or above 30. Third, we constraint the variable to be within a particular interval, according to the highest level of education attained. There are six educational levels in EU-SILC (pe040): 0 pre-primary; 1 primary; 2 lower secondary; 3 (upper) secondary; 4 post-secondary non-tertiary; 5 tertiary. We exclude individuals with pe040 $=1$ and more than 12 years of education, those with pe040 = 2 and more than 14 years of education, those with pe $040=3$ and more than 17 years of education, those with pe $040=4$ and more than 25 years of education, and those with pe $040=5$ and more than 27 years of education. We also exclude individuals with too little education, given their education level: those with pe040 $=3$ and less than 10 years of education and those with pe040 $=5$ and less than 14 years of 

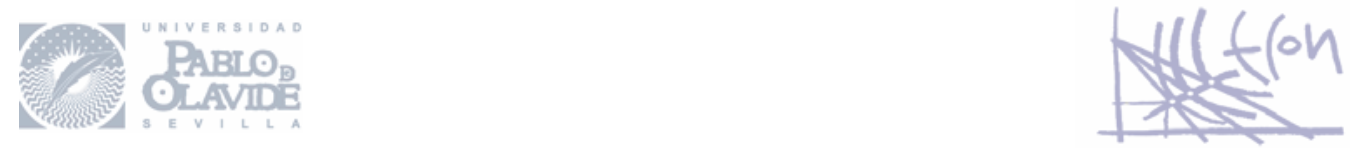

education. Finally, we exclude individuals with less than 4 years of education and those who ended education at the age of 35 or later.

Secondary education (SE): A dummy variable that takes value 1 for those individuals with ISCED level 3 or higher.

Tertiary education (HE): A dummy variable that takes value 1 for those individuals with ISCED level 5.

Poor family (poor_past): Individuals are asked how frequent financial problems in the household were when they were young teenagers (age 14). In the 2005 cross section, it is a categorical variable taking five possible values: 1 (most of the time), 2 (often), 3 (occasionally), 4 (rarely), and 5 (never). In the 2011 cross section there are six possible answers: 1 (very bad), 2 (bad), 3 (moderately bad), 4 (moderately good), 5 (good), and 6 (very good). We summarize the information of these questions by constructing a binary variable that takes value 1 when the corresponding variable is either 1 or 2 in the 2005 cross section and when it is 1 , 2, or 3 in the 2011 cross section. ${ }^{28}$ We lose some observations from the 2005 wave since four countries do not report this variable in that wave (Austria, France, Greece, and Portugal).

Parental education (non_educated_family): A dummy variable that is one if neither the father nor the mother attained a medium education level (upper secondary and post-secondary nontertiary education).

Non-citizen: A dummy variable that takes value 1 if the individual is not a citizen of the country where he/she lives (when pb220a is different from “LOC”).

Lived with father only (father_only): A dummy variable that takes value 1 if the individual lived with young with the father only (when pt010 = 2).

28 The way in which we code this variable guarantees that we have similar frequencies of the variable poor_past in the two cross sections. 
Reform dummy (reform): a dummy value that takes value 1 for individuals affected by the reforms, and 0 otherwise.

Compulsory education (years_comp): the number of years of education that each individual is required to attend.

Disposable income: We use the variable hy022, total disposable household income before social transfers, other than old-age and survivor benefits.

\section{Variables from ESS}

Good health: A dummy variable that takes value 1 if the individual reports to have either good or very good health (health is either 1 or 2). Individuals are asked, "How is your health in general? Would you say it is ...” Possible answers are: very good, good, fair, bad, very bad.

Not limited: A dummy variable that takes value 1 if the individual reports to be not limited in daily life $($ hlthhmp $=3)$. Individuals are asked, "Are you hampered in your daily activities in any way by any longstanding illness, or disability, infirmity or mental health problem? If yes, is that a lot or to some extent?” Possible answers are: Yes a lot, yes to some extent, no.

The rest of variables used in the analysis with ESS are constructed in a similar way as those from EU-SILC. 


\section{Date}

\section{B. Summary of reforms}

Austria: A reform of compulsory education was passed in 1962, raising the school leaving age from 14 to 15. The number of years of compulsory education was increased from 8 to 9 . The law came into effect on September 1 in 1966 (Fort et al., 2016). Those who turn 14 before September $1^{\text {st }} 1966$ could not be affected. As Gathmann et al. (2015), we code those born in 1953 as the first cohort affected by this reform.

Czech Republic and Slovakia: Several educational reforms were implemented in former Czechoslovakia after WWII. Garrouste (2010) reports reforms in 1948, 1953, 1960, 1979, and 1990. Brunello et al. (2017) use the reforms of 1948, 1953, and 1960. Those of 1948, 1960 and 1990 increased the length of compulsory education from 8 years to 9, while those of 1953 and 1979 reduced it from 9 years to 8 . We use the reform of 1960 . School leaving age was increased from 14 to 15 years. The first cohort potentially affected by this reform are those born in 1946, since they turn 14 in 1960.

France: Compulsory schooling was increased in 1967 from 8 to 10 years. School leaving age raised from 14 to 16 years (Albouy and Lecquien, 2009; Gathmann et al., 2015, Brunello et al., 2009; Borgonovi et al., 2010). The first cohort potentially affected are those born in 1953. According to Grenet (2013), the French reform of 1959 affected all people born on or after January 1, 1953.

Greece: In 1976 Greece raised years of compulsory education from 6 to 9 (Law 309/1976). School leaving age was raised from 12 to 15 years (Murtin and Viarengo, 2011; Garrouste, 2010). The first cohort potentially affected are those born in 1964.

Ireland: The reform of 1972 increased school leaving age from 14 to 15 (Murtin and Viarengo, 2011; Mocan and Pogorelova, 2017). Cohorts born in 1958 and later were affected. 


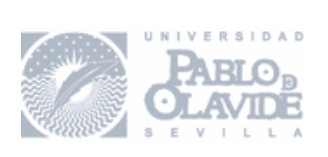

Italy: A reform that made junior high school compulsory was passed at the end of 1962 and implemented in 1963. Years of compulsory education were raised from 5 to 8 and school leaving age increased from 11 to 14 (Fort, 2006). Different authors propose different cohorts as the one first affected. According to Brandolini and Cipollone (2002), the cohort of 1952 was fully affected. We follow them, and code 1951 as the first cohort potentially affected.

Malta: In Malta the 1974 prolongation of compulsory education from 14 to 16 led to a dramatic increase in the student population, according to Kallen (1998). The number of years of compulsory education was increased from 8 to 10 . The first cohort affected should be those born in 1960 since they turn 14 in 1974.

The Netherlands: Several reforms were passed in the $20^{\text {th }}$ century. Most authors use the reform of 1975 that increased minimum school leaving age from 15 to 16 (Brunello et al., 2009; Gathmann et al., 2015; Fort, 2006). All students born after August 1, 1959 should complete 10 years of education. All cohorts born in 1960 and after should be affected.

Poland: On July 15th 1961, the Polish Parliament passed a reform of the educational system raising the minimum age of graduation from 14 to 15 . The reform was implemented gradually from 1962 to $1966 .{ }^{29}$ Cohorts fully affected by this reform are those born in 1952 (they turn 14 in 1966).

Portugal: In 1964, compulsory schooling was increased from 12 to 14 years, establishing 6 years of compulsory schooling. According to Vieira (1999) and Brunello et al. (2013), the first cohort affected was the cohort of 1956.

\footnotetext{
29 “Education in the Polish People's Republic”, Wikipedia.
} 
United Kingdom: In March 1972, minimum school leaving age was increased from 15 to 16, starting in September 1, 1972. Since school entry age was 5, the number of years of compulsory education raised from 10 years to 11. All individuals born September 1957 or later were affected by this reform (Fort, 2006; Gathmann et al., 2015). We take all cohorts born 1958 or later as affected by the reform. 


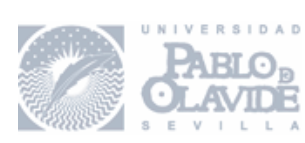

\section{Countries not included}

Denmark: Most of the literature reports two reforms in Denmark. The first one in 1958 raised compulsory schooling from 4 to 7 years. See Brunello et al. (2016), d'Hombres and Nunziata (2016), and Cavaille and Marshall (2019). Most of them set 1944 as the first cohort affected. However, there is some controversy on the details of the reform. While Brunello et al. (2016), d'Hombres and Nunziata (2016) refer an increase of years of compulsory education from 4 to 7, Cavaille and Marshall (2019) claim that compulsory education was increased from 7 to 8 years. The second reform was implemented in 1975 (Arendt, 2005). Most papers in the literature mention an increase of compulsory education from 7 to 9 years, and fix 1957 as the first cohort affected. See Mocan and Pogorelova (2017), Brunello et al. (2009), Gathmann et al. (2015), Meyer (2017). However, according to Arendt (2005), this reform had little impact since most children already obtained 9 years of schooling.

Hungary: According to Borgonovi et al. (2010), Hungary increased the length of compulsory education from 8 to 10 years in 1961, raising minimum school leaving age from 14 to 16 . The first cohort potentially affected is the cohort of 1947 since they turn 14 in 1961 . See also Mocan and Pogorelova (2017). Following the bulk of the literature, we do not include this reform.

Spain: Several authors (Gathmann et al., 2015; Borgonovi et al., 2010; Brunello et al., 2009; Fort, 2006) have proposed to use the reform of 1970. This reform increased minimum school leaving age from 12 to 14 (years of compulsory education from 6 to 8). Here the first cohort affected should be the cohort of 1957. The problem is that this reform was implemented gradually. In 1970-71, the first four grades of primary education (EGB, "Enseñanza General Básica”) were implemented. In 1971-72, it was implemented the fifth grade, in 1972-73 the sixth grade, in 1973-74 the seventh grade, and in 1974-75 the eighth grade. 


\section{Additional figures and tables}

Figure 01: Average years of education and health measures: different age intervals

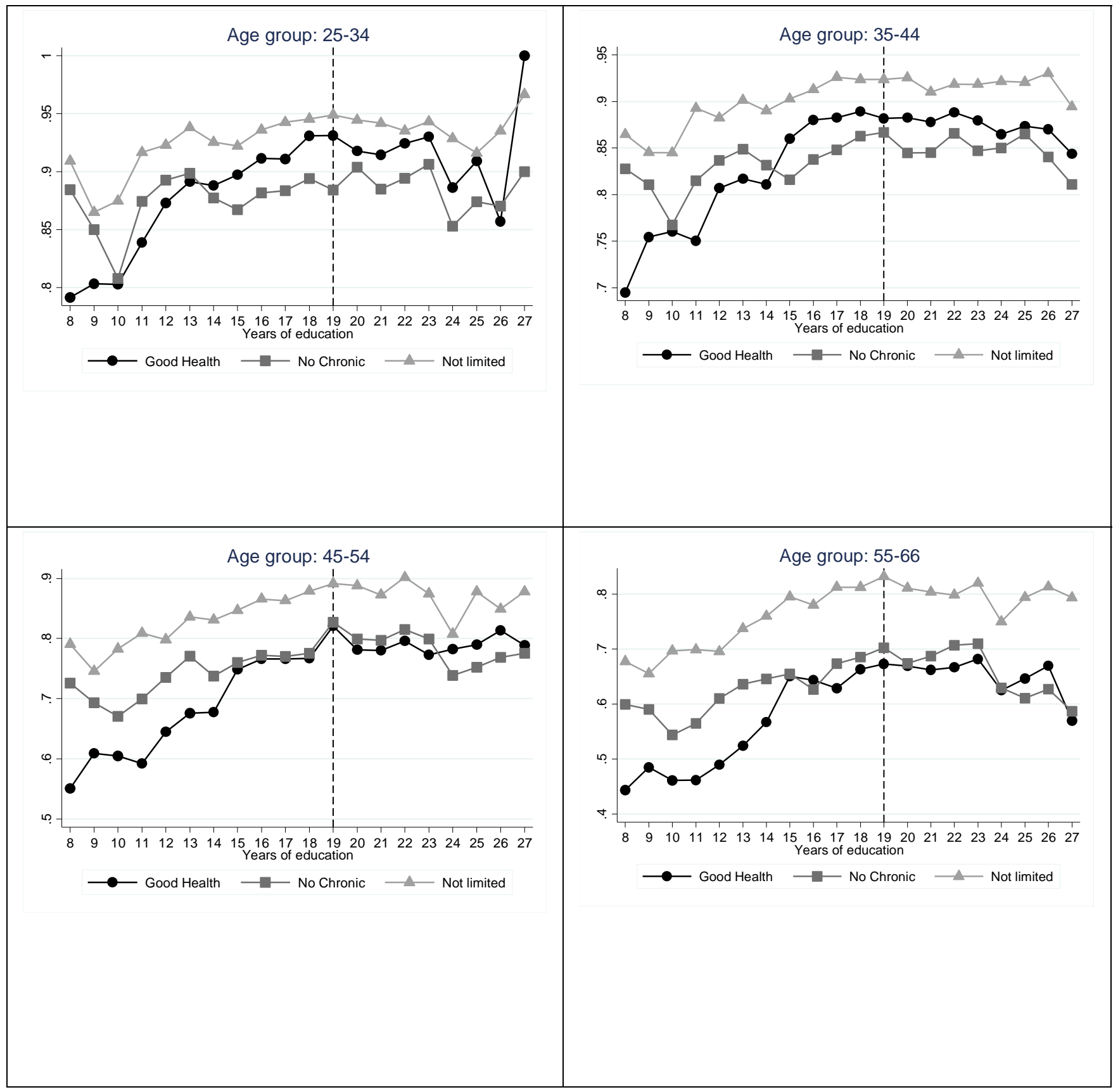


Figure O2: Average years of education and health measures by country
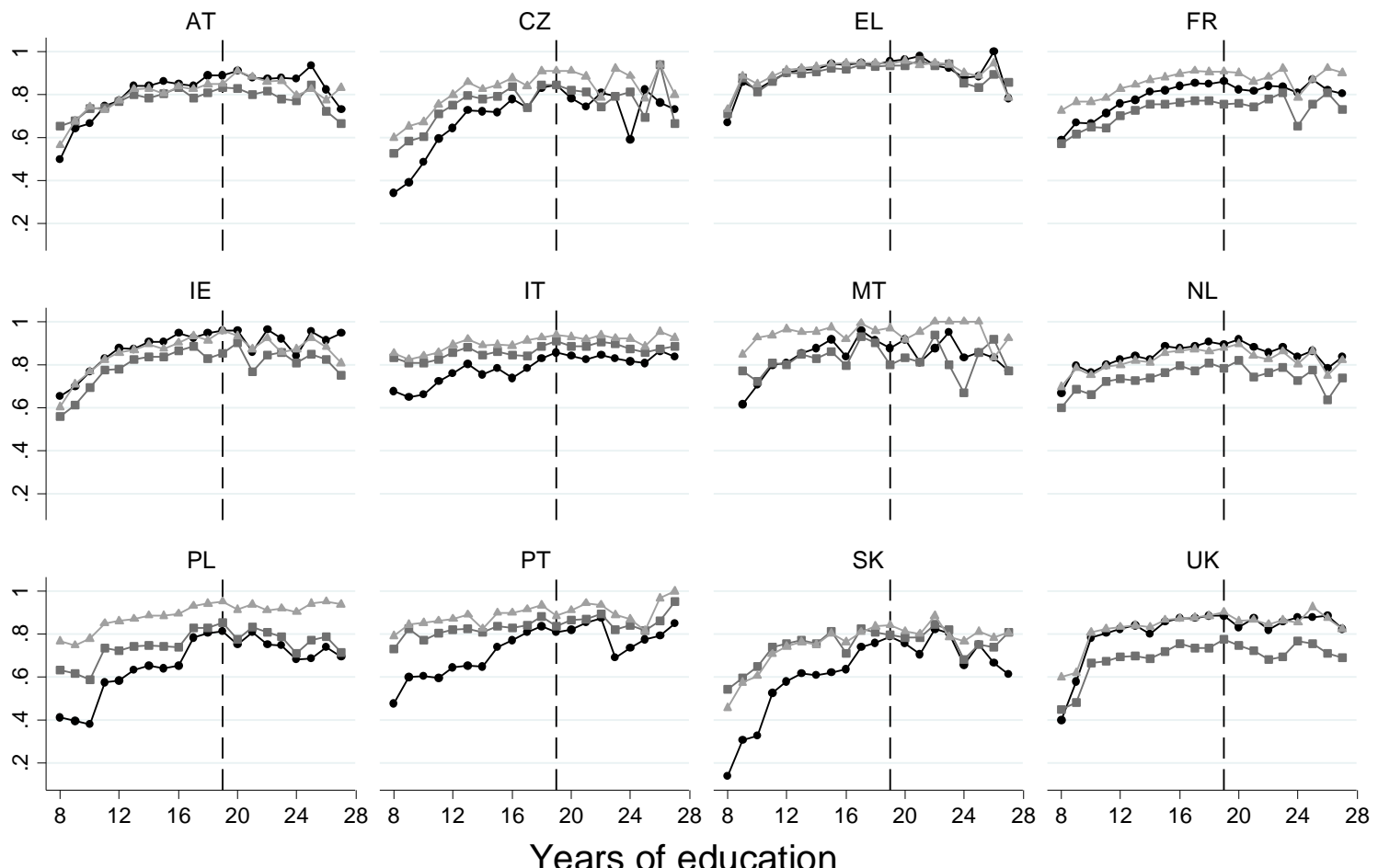
Years of education 
Table 01: Summary Statistics

\begin{tabular}{lccccc} 
Variable & Mean & Std. Dev. & Min & Max & Obs. \\
\hline Female & 0.536 & 0.499 & 0 & 1 & 47269 \\
Age & 53.251 & 5.139 & 39 & 66 & 47269 \\
Years of education & 11.124 & 3.373 & 4 & 19 & 47269 \\
Years of compulsory education & 8.015 & 1.522 & 4 & 11 & 47269 \\
Having at least secondary educ. & 0.620 & 0.485 & 0 & 1 & 47269 \\
Having tertiary education & 0.109 & 0.312 & 0 & 1 & 47269 \\
Reporting good health & 0.549 & 0.498 & 0 & 1 & 47069 \\
Not limited & 0.773 & 0.419 & 0 & 1 & 47011 \\
No chronic & 0.671 & 0.470 & 0 & 1 & 47029 \\
Poor family & 0.382 & 0.486 & 0 & 1 & 47269 \\
Non educated family & 0.756 & 0.430 & 0 & 1 & 45970 \\
Non-citizen & 0.001 & 0.023 & 0 & 1 & 47269 \\
Lived with father only & 0.014 & 0.118 & 0 & 1 & 47260
\end{tabular}

Sample size by country

$\begin{array}{lc}\text { AT } & 1252 \\ \text { CZ } & 2424 \\ \text { EL } & 2377 \\ \text { FR } & 2256 \\ \text { IE } & 2371 \\ \text { IT } & 11988 \\ \text { MT } & 1801 \\ \text { NL } & 3043 \\ \text { PL } & 12176 \\ \text { PT } & 1743 \\ \text { SK } & 2707 \\ \text { UK } & 3131 \\ \text { Total } & 47,269\end{array}$

Notes: The sample corresponds to a window size of 7 years and contains all individuals for which the reform dummy and poor past are not missing. Source: EU-SILC 2005 and 2011. 
Table O2: Second Stage results using years of compulsory education as instrument

\begin{tabular}{|c|c|c|c|c|c|c|c|}
\hline & $\begin{array}{c}\text { I } \\
\text { All }\end{array}$ & $\begin{array}{c}\text { II } \\
\text { Men }\end{array}$ & $\begin{array}{c}\text { III } \\
\text { Women }\end{array}$ & $\begin{array}{c}\text { IV } \\
\text { Non poor }\end{array}$ & $\begin{array}{c}\mathrm{V} \\
\text { Poor }\end{array}$ & $\begin{array}{c}\text { VI } \\
\text { Educated }\end{array}$ & $\begin{array}{c}\text { VII } \\
\text { Non educated }\end{array}$ \\
\hline \multicolumn{8}{|c|}{ A. Dependent variable is good health reported } \\
\hline $\begin{array}{l}\text { OLS coefficient of } \\
\text { years of schooling }\end{array}$ & $\begin{array}{c}0.020^{* * *} \\
(0.001)\end{array}$ & $\begin{array}{c}0.018 * * * \\
(0.001)\end{array}$ & $\begin{array}{c}0.022^{* * *} \\
(0.001)\end{array}$ & $\begin{array}{c}0.020^{* * *} \\
(0.001)\end{array}$ & $\begin{array}{c}0.017^{* * *} \\
(0.001)\end{array}$ & $\begin{array}{c}0.024 * * * \\
(0.002)\end{array}$ & $\begin{array}{c}0.019 * * * \\
(0.001)\end{array}$ \\
\hline $\begin{array}{l}\text { IV coefficient of } \\
\text { years of schooling }\end{array}$ & $\begin{array}{c}0.018 \\
(0.034)\end{array}$ & $\begin{array}{c}0.012 \\
(0.041)\end{array}$ & $\begin{array}{c}0.022 \\
(0.049)\end{array}$ & $\begin{array}{c}0.058 \\
(0.059)\end{array}$ & $\begin{array}{c}0.007 \\
(0.037)\end{array}$ & $\begin{array}{c}2.275 \\
(11.430)\end{array}$ & $\begin{array}{l}-0.010 \\
(0.033)\end{array}$ \\
\hline Observations & 45,767 & 21,172 & 24,595 & 28,237 & 17,530 & 11,162 & 34,605 \\
\hline \multicolumn{8}{|c|}{ B. Dependent variable is not limited in daily activities } \\
\hline $\begin{array}{l}\text { OLS coefficient of } \\
\text { years of schooling }\end{array}$ & $\begin{array}{c}0.013^{* * *} \\
(0.001)\end{array}$ & $\begin{array}{c}0.013^{* * *} \\
(0.001)\end{array}$ & $\begin{array}{c}0.013^{* * *} \\
(0.001)\end{array}$ & $\begin{array}{c}0.014^{* * *} \\
(0.001)\end{array}$ & $\begin{array}{c}0.013^{* * *} \\
(0.001)\end{array}$ & $\begin{array}{c}0.014 * * * \\
(0.001)\end{array}$ & $\begin{array}{c}0.014^{* * *} \\
(0.001)\end{array}$ \\
\hline $\begin{array}{l}\text { IV coefficient of } \\
\text { years of schooling }\end{array}$ & $\begin{array}{l}-0.008 \\
(0.030)\end{array}$ & $\begin{array}{c}0.011 \\
(0.042)\end{array}$ & $\begin{array}{l}-0.027 \\
(0.044)\end{array}$ & $\begin{array}{c}0.001 \\
(0.044)\end{array}$ & $\begin{array}{l}-0.011 \\
(0.047)\end{array}$ & $\begin{array}{l}-0.266 \\
(1.862)\end{array}$ & $\begin{array}{l}-0.017 \\
(0.029)\end{array}$ \\
\hline Observations & 45,710 & 21,136 & 24,574 & 28,202 & 17,508 & 11,151 & 34,559 \\
\hline \multicolumn{8}{|c|}{ C. Dependent variable is no chronic } \\
\hline $\begin{array}{l}\text { OLS coefficient of } \\
\text { years of schooling }\end{array}$ & $\begin{array}{c}0.010 * * * \\
(0.001)\end{array}$ & $\begin{array}{c}0.009 * * * \\
(0.001)\end{array}$ & $\begin{array}{l}0.012 * * * \\
(0.001)\end{array}$ & $\begin{array}{c}0.011^{* * *} \\
(0.001)\end{array}$ & $\begin{array}{c}0.009 * * * \\
(0.001)\end{array}$ & $\begin{array}{c}0.012 * * * \\
(0.002)\end{array}$ & $\begin{array}{c}0.010 * * * \\
(0.001)\end{array}$ \\
\hline $\begin{array}{l}\text { IV coefficient of } \\
\text { years of schooling }\end{array}$ & $\begin{array}{l}-0.005 \\
(0.035)\end{array}$ & $\begin{array}{l}-0.038 \\
(0.040)\end{array}$ & $\begin{array}{c}0.038 \\
(0.047)\end{array}$ & $\begin{array}{l}-0.053 \\
(0.061)\end{array}$ & $\begin{array}{c}0.060 \\
(0.040)\end{array}$ & $\begin{array}{c}0.804 \\
(3.553)\end{array}$ & $\begin{array}{l}-0.014 \\
(0.034)\end{array}$ \\
\hline Observations & 45,728 & 21,150 & 24,578 & 28,216 & 17,512 & 11,154 & 34,574 \\
\hline
\end{tabular}

Note: The instrument is years comp. Robust standard errors in parentheses; ${ }^{* * *} \mathrm{p}<0.01,{ }^{* *} \mathrm{p}<0.05$, ${ }^{*} \mathrm{p}<0.1$. See Table 2, Panel B, for the results corresponding to the first stage. 


\section{D d}

\section{Robustness checks}

\section{D.1 Alternative specification}

We estimate an alternative model in which we include as additional instrument the interaction between the reform dummy and the dummy that captures parents' education. Parental education has been shown to be the most important factor in explaining the education of their children. ${ }^{30}$ We conjecture that this effect should depend on how much parents value children's education. Individuals whose parents have a high educational level, most likely will not be affected by the reform, since they would surely have chosen a higher educational level than the one imposed by the reform anyway. On the contrary, for those individuals from families with little education we expect a stronger effect, since they were more likely to leave school just at the end of the compulsory period. The exclusion restriction will hold if the effect of either of these two variables on health does not depend directly on whether the individual was born before or after the reform. There may be an effect, but again we assume this effect operates indirectly through the education level of the individual. ${ }^{31}$ In this specification, we also include separate time trends according to parental education, specific of each country. Since time trends may depend on family education, if we do not include these differential time trends, we may end up attributing to reforms an effect on particular

\footnotetext{
${ }^{30}$ See, among others, the review by Haveman and Wolfe (1995). The existing literature on the intergenerational transmission of education provides some evidence on the potential transmission channels, for instance, labor-market effects, better home environments (Carneiro et $a l$, 2013) or the fact that more schooling can increase parents' valuation of children's education (Piopiunik, 2014).

${ }^{31}$ Borgonovi et al. (2010) use the interaction between the reform dummy and parental education level as an instrument for individuals' education. Brunello et al. (2017) use as an instrument an interaction term between years of compulsory education and a dummy variable capturing whether the individual lived in a rural area or not. Similar to us, both studies find that reforms only affect individuals with low SES (low-educated parents and living in rural areas, respectively).
} 
groups that simply comes from a steeper long-term increase in education. In other words, the variation we have identified is not truly exogenous.

The results are in Table O3. We report the results for all individuals (Column I), and separately by gender (columns II and III). In Panel A, we present the first-stage results. Since we have two instruments, we can compute the effect of CSL for all individuals ("Overall”) and according to parental education. The results are in line with those of Table 2 in the main text. The effect of CSL concentrates on individuals from low educated families. In Panel B, we present the results for the main equation. As in Table 3 in the main text, we cannot identify a causal effect of education on health. 
Table O3: We include as additional instrument an interaction term between the reform dummy and the family education dummy

\begin{tabular}{|c|c|c|c|}
\hline & All & Men & Women \\
\hline \multicolumn{4}{|c|}{ A. Effect of the reform on years of education } \\
\hline Overall & $\begin{array}{c}0.350 * * * \\
(0.069)\end{array}$ & $\begin{array}{c}0.338 * * * \\
(0.099)\end{array}$ & $\begin{array}{c}0.358 * * * \\
(0.077)\end{array}$ \\
\hline \multicolumn{4}{|c|}{ Decomposition by parental education } \\
\hline Educated family & $\begin{array}{c}0.041 \\
(0.100)\end{array}$ & $\begin{array}{c}0.026 \\
(0.137)\end{array}$ & $\begin{array}{c}0.058 \\
(0.153)\end{array}$ \\
\hline Non educated family & $\begin{array}{c}0.450 * * * \\
(0.072)\end{array}$ & $\begin{array}{c}0.436 * * * \\
(0.107)\end{array}$ & $\begin{array}{c}0.456 * * * \\
(0.081)\end{array}$ \\
\hline Difference test p-value & $<0.0001$ & 0.0029 & 0.0138 \\
\hline 1st stage F-test & 23.64 & 9.56 & 16.14 \\
\hline P-value & $<0.0001$ & 0.0001 & $<0.0001$ \\
\hline \multicolumn{4}{|c|}{ B. Effect of education on health outcomes } \\
\hline Good health & $\begin{array}{c}0.036 \\
(0.027)\end{array}$ & $\begin{array}{c}0.055 \\
(0.038)\end{array}$ & $\begin{array}{c}0.020 \\
(0.032)\end{array}$ \\
\hline Not limited & $\begin{array}{c}0.013 \\
(0.023)\end{array}$ & $\begin{array}{c}0.032 \\
(0.035)\end{array}$ & $\begin{array}{l}-0.002 \\
(0.029)\end{array}$ \\
\hline No chronic illness & $\begin{array}{c}0.019 \\
(0.024)\end{array}$ & $\begin{array}{l}-0.004 \\
(0.033)\end{array}$ & $\begin{array}{c}0.043 \\
(0.034)\end{array}$ \\
\hline Observations & 45,767 & 21,172 & 24,595 \\
\hline
\end{tabular}

Notes: We use two instruments for years of education: i) the reform dummy and ii) its interaction with the variable describing parental education. We also add a different countryspecific time trend for each value of parental education. Since we have an interaction term in the first-stage, we can calculate the marginal effect of the reform dummy for all individuals (overall) and separated according to parental education (decomposition). 


\section{D.2 Alternative measures of education}

Table 04: Including individuals with up to 27 years of education

\begin{tabular}{|c|c|c|c|c|c|c|c|}
\hline & $\begin{array}{c}\text { I } \\
\text { All }\end{array}$ & $\begin{array}{c}\text { II } \\
\text { Men }\end{array}$ & $\begin{array}{c}\text { III } \\
\text { Women }\end{array}$ & $\begin{array}{c}\text { IV } \\
\text { Non Poor }\end{array}$ & $\begin{array}{c}\mathrm{V} \\
\text { Poor }\end{array}$ & $\begin{array}{c}\text { VI } \\
\text { Educated }\end{array}$ & $\begin{array}{c}\text { VII } \\
\text { Non educated }\end{array}$ \\
\hline \multicolumn{8}{|c|}{$\begin{array}{l}\text { A. Dependent variable is good health } \\
\text { reported }\end{array}$} \\
\hline $\begin{array}{l}\text { OLS coefficient of } \\
\text { years of schooling }\end{array}$ & $\begin{array}{c}0.015^{* * *} \\
(0.001)\end{array}$ & $\begin{array}{c}0.013^{* * *} \\
(0.001)\end{array}$ & $\begin{array}{c}0.017 * * * \\
(0.001)\end{array}$ & $\begin{array}{c}0.015^{* * *} \\
(0.001)\end{array}$ & $\begin{array}{c}0.014^{* * *} \\
(0.001)\end{array}$ & $\begin{array}{c}0.015^{* * *} \\
(0.001)\end{array}$ & $\begin{array}{c}0.015^{* * *} \\
(0.001)\end{array}$ \\
\hline $\begin{array}{l}\text { IV coefficient of } \\
\text { years of schooling }\end{array}$ & $\begin{array}{c}0.031 \\
(0.032)\end{array}$ & $\begin{array}{c}0.004 \\
(0.032)\end{array}$ & $\begin{array}{c}0.073 \\
(0.055)\end{array}$ & $\begin{array}{c}0.075 \\
(0.073)\end{array}$ & $\begin{array}{c}0.014 \\
(0.026)\end{array}$ & $\begin{array}{c}0.336 \\
(0.512)\end{array}$ & $\begin{array}{c}0.008 \\
(0.030)\end{array}$ \\
\hline \multicolumn{8}{|c|}{ B. Dependent variable is not limited in daily activities } \\
\hline $\begin{array}{l}\text { OLS coefficient of } \\
\text { years of schooling }\end{array}$ & $\begin{array}{c}0.010 * * * \\
(0.001)\end{array}$ & $\begin{array}{l}0.010^{* * *} \\
(0.001)\end{array}$ & $\begin{array}{c}0.010^{* * *} \\
(0.001)\end{array}$ & $\begin{array}{c}0.010^{* * *} \\
(0.001)\end{array}$ & $\begin{array}{c}0.011^{* * *} \\
(0.001)\end{array}$ & $\begin{array}{c}0.010^{* * *} \\
(0.001)\end{array}$ & $\begin{array}{c}0.011^{* * *} \\
(0.001)\end{array}$ \\
\hline $\begin{array}{l}\text { IV coefficient of } \\
\text { years of schooling }\end{array}$ & $\begin{array}{c}0.005 \\
(0.027)\end{array}$ & $\begin{array}{c}0.004 \\
(0.031)\end{array}$ & $\begin{array}{c}0.007 \\
(0.048)\end{array}$ & $\begin{array}{c}0.014 \\
(0.056)\end{array}$ & $\begin{array}{l}-0.000 \\
(0.031)\end{array}$ & $\begin{array}{l}-0.139 \\
(0.259)\end{array}$ & $\begin{array}{c}0.009 \\
(0.024)\end{array}$ \\
\hline \multicolumn{8}{|c|}{ C. Dependent variable is no chronic } \\
\hline $\begin{array}{l}\text { OLS coefficient of } \\
\text { years of schooling }\end{array}$ & $\begin{array}{c}0.007 * * * \\
(0.001)\end{array}$ & $\begin{array}{c}0.006^{* * *} \\
(0.001)\end{array}$ & $\begin{array}{c}0.009 * * * \\
(0.001)\end{array}$ & $\begin{array}{c}0.008 * * * \\
(0.001)\end{array}$ & $\begin{array}{c}0.006^{* * *} \\
(0.001)\end{array}$ & $\begin{array}{c}0.008 * * * \\
(0.001)\end{array}$ & $\begin{array}{c}0.007 * * * \\
(0.001)\end{array}$ \\
\hline $\begin{array}{l}\text { IV coefficient of } \\
\text { years of schooling }\end{array}$ & $\begin{array}{c}0.032 \\
(0.032)\end{array}$ & $\begin{array}{l}-0.017 \\
(0.034)\end{array}$ & $\begin{array}{l}0.118^{*} \\
(0.067)\end{array}$ & $\begin{array}{c}0.044 \\
(0.065)\end{array}$ & $\begin{array}{c}0.030 \\
(0.031)\end{array}$ & $\begin{array}{c}0.218 \\
(0.324)\end{array}$ & $\begin{array}{c}0.014 \\
(0.029)\end{array}$ \\
\hline $\begin{array}{l}\text { First-Stage } \\
\text { 1st stage } \\
\text { coefficient }\end{array}$ & $0.346^{* * *}$ & $0.452^{* * *}$ & $0.243^{* *}$ & $0.218^{* *}$ & $0.584^{* * *}$ & $(0.134)$ & $0.415^{* * *}$ \\
\hline $\begin{array}{l}\text { 1st stage F-test } \\
\text { P-value }\end{array}$ & $\begin{array}{c}22.496 \\
0.000\end{array}$ & $\begin{array}{c}20.665 \\
0.000\end{array}$ & $\begin{array}{l}6.514 \\
0.012\end{array}$ & $\begin{array}{l}4.738 \\
0.031\end{array}$ & $\begin{array}{c}18.564 \\
0.000\end{array}$ & $\begin{array}{l}0.574 \\
0.450\end{array}$ & $\begin{array}{c}24.199 \\
0.000\end{array}$ \\
\hline Observations & 48,234 & 22,671 & 25,563 & 30,132 & 18,102 & 12,409 & 35,825 \\
\hline
\end{tabular}




\section{D.3 Using data from the European Social Survey}

Another criticism of our approach could be that the negative result we get is very specific of the database we use (EU-SILC). What we can do is to see if we get a similar result using a comparable dataset. In particular, we replicate the analysis using micro data from the European Social Survey (ESS). The ESS contains information on education and health outcomes, although the information on SES is less detailed. The education measure we use is the number of years of education ("eduyrs"), while the two measures of health are: i) a measure of subjective general health (“health”) and ii) a measure of whether or not the subject is hampered in daily activities by illness or disability or mental problems (“hlthhmp”). Both variables are categorical, and we use them to construct two dummy variables similar to our variables good health, and not limited. ${ }^{32}$ To have a sample as comparable as possible to the one from EU-SILC, we use data from eleven countries in the ESS, and from the eight rounds that go from 2002 to 2016. We cannot use data from Malta, since it is not included in ESS. The ESS contains information on the educational level of parents, which allows us to build a measure of family education similar to the one we have in EU-SILC. The results are in Table O5. The OLS coefficients are similar in size to those in Table 3, where we use EU-SILC. The first difference we find with our main specification in Table 3 is that now the instrument is much weaker. One reason for this is that the sample size in ESS is lower. The F-statistic of the first-stage is above ten only on the subsample of women. With the whole sample, it is only 8.25. In any case, again we find no significant effect of education on any of the two health outcomes.

\footnotetext{
${ }^{32}$ The variable health has exactly the same five categories as the one from EU-SILC. The variable hlthhmp has three categories: "Yes a lot," "Yes," and "No."
} 
Table O5: Results using the European Social Survey

\begin{tabular}{|c|c|c|c|c|c|}
\hline & I & II & III & IV & $\mathrm{V}$ \\
\hline & All & Men & Women & Educated & Non educated \\
\hline \multicolumn{6}{|c|}{ A. Dependent variable is good health reported } \\
\hline $\begin{array}{l}\text { OLS coefficient of } \\
\text { years of schooling }\end{array}$ & $\begin{array}{c}0.023^{* * *} \\
(0.001)\end{array}$ & $\begin{array}{c}0.022 * * * \\
(0.001)\end{array}$ & $\begin{array}{c}0.023^{* * *} \\
(0.001)\end{array}$ & $\begin{array}{c}0.022^{* * *} \\
(0.002)\end{array}$ & $\begin{array}{c}0.023 * * * \\
(0.001)\end{array}$ \\
\hline $\begin{array}{l}\text { IV coefficient of } \\
\text { years of schooling }\end{array}$ & $\begin{array}{c}0.029 \\
(0.064)\end{array}$ & $\begin{array}{c}0.048 \\
(0.242)\end{array}$ & $\begin{array}{c}0.024 \\
(0.054)\end{array}$ & $\begin{array}{c}0.189 \\
(0.145)\end{array}$ & $\begin{array}{l}-0.041 \\
(0.072)\end{array}$ \\
\hline \multicolumn{6}{|c|}{ B. Dependent variable is not limited in daily activities } \\
\hline $\begin{array}{l}\text { OLS coefficient of } \\
\text { years of schooling }\end{array}$ & $\begin{array}{c}0.015^{* * *} \\
(0.001)\end{array}$ & $\begin{array}{c}0.016^{* * *} \\
(0.001)\end{array}$ & $\begin{array}{c}0.015^{* * *} \\
(0.001)\end{array}$ & $\begin{array}{c}0.016 * * * \\
(0.002)\end{array}$ & $\begin{array}{c}0.015 * * * \\
(0.001)\end{array}$ \\
\hline $\begin{array}{l}\text { IV coefficient of } \\
\text { years of schooling }\end{array}$ & $\begin{array}{l}-0.017 \\
(0.049)\end{array}$ & $\begin{array}{l}-0.247 \\
(0.438)\end{array}$ & $\begin{array}{c}0.022 \\
(0.039)\end{array}$ & $\begin{array}{l}-0.009 \\
(0.118)\end{array}$ & $\begin{array}{l}-0.023 \\
(0.052)\end{array}$ \\
\hline \multicolumn{6}{|c|}{ First-Stage } \\
\hline 1st stage coefficient & $\begin{array}{c}0.209 * * * \\
(0.073)\end{array}$ & $\begin{array}{c}0.073 \\
(0.106)\end{array}$ & $\begin{array}{c}0.300 * * * \\
(0.082)\end{array}$ & $\begin{array}{l}0.137^{*} \\
(0.080)\end{array}$ & $\begin{array}{l}0.241 * * \\
(0.101)\end{array}$ \\
\hline 1st stage F-test & 8.258 & 0.476 & 13.516 & 2.906 & 5.696 \\
\hline P-value & 0.005 & 0.491 & 0.000 & 0.090 & 0.018 \\
\hline Observations & 31,190 & 13,868 & 17,322 & 11,603 & 19,587 \\
\hline
\end{tabular}

Notes: We use data from only eleven countries, since we lack data from MT in ESS. Window of 7 years, errors clustered at the country cohort-of-birth level. All models include as control variables noncitizen, country-specific quadratic trends, cohort fixed effects, and survey fixed effects. 


\section{D.4 Country selection}

The countries we use in our analysis are those for which we have reliable information on CSL, and where reforms have a positive effect on education levels. It could be that our results are driven by one specific country. We check this by estimating again the model in Column I of Table 3, excluding one country at a time. The results, very close to those of Table 3, are in Table O6 below. 
Table O6: Removing one country at a time

\begin{tabular}{|c|c|c|c|c|c|c|c|c|c|c|c|c|}
\hline & (1) & $(2)$ & (3) & (4) & (5) & $(6)$ & $(7)$ & $(8)$ & (9) & (10) & (11) & (12) \\
\hline VARIABLES & Austria & Czech R. & Greece & France & Ireland & Italy & Malta & Netherlands & Poland & Portugal & Slovakia & UK \\
\hline & \multicolumn{12}{|c|}{ A. Dependent variable is good health reported } \\
\hline Years of & 0.033 & 0.015 & 0.038 & 0.032 & 0.028 & 0.029 & 0.035 & 0.019 & 0.004 & 0.011 & 0.041 & 0.035 \\
\hline education & $(0.029)$ & $(0.029)$ & $(0.031)$ & $(0.031)$ & $(0.036)$ & $(0.030)$ & $(0.034)$ & $(0.029)$ & $(0.033)$ & $(0.038)$ & $(0.030)$ & $(0.027)$ \\
\hline \multirow[t]{2}{*}{ Observations } & 44,517 & 43,449 & 43,657 & 43,566 & 43,420 & 33,871 & 43,994 & 42,876 & 33,951 & 44,054 & 43,160 & 42,922 \\
\hline & \multicolumn{12}{|c|}{ B. Dependent variable is not limited in daily activities } \\
\hline Years of & 0.020 & -0.009 & 0.017 & 0.005 & 0.033 & 0.024 & 0.018 & 0.008 & -0.013 & 0.009 & 0.017 & 0.012 \\
\hline education & $(0.025)$ & $(0.026)$ & $(0.027)$ & $(0.028)$ & $(0.030)$ & $(0.024)$ & $(0.029)$ & $(0.025)$ & $(0.027)$ & $(0.034)$ & $(0.025)$ & $(0.027)$ \\
\hline \multirow[t]{2}{*}{ Observations } & 44,460 & 43,392 & 43,600 & 43,508 & 43,364 & 33,866 & 43,935 & 42,820 & 33,894 & 43,997 & 43,109 & 42,865 \\
\hline & \multicolumn{12}{|c|}{ C. Dependent variable is no chronic illness } \\
\hline Years of & 0.040 & 0.024 & 0.043 & 0.038 & 0.033 & $0.054 *$ & 0.038 & 0.030 & 0.011 & 0.039 & 0.039 & $0.050 *$ \\
\hline education & $(0.030)$ & $(0.030)$ & $(0.031)$ & $(0.032)$ & $(0.030)$ & $(0.028)$ & $(0.034)$ & $(0.030)$ & $(0.036)$ & $(0.039)$ & $(0.031)$ & $(0.028)$ \\
\hline \multirow[t]{2}{*}{ Observations } & 44,478 & 43,410 & 43,618 & 43,530 & 43,364 & 33,859 & 43,955 & 42,839 & 33,912 & 44,015 & 43,127 & 42,884 \\
\hline & \multicolumn{12}{|c|}{ D. First-Stage } \\
\hline $\begin{array}{l}\text { 1st stage } \\
\text { coefficient }\end{array}$ & $\begin{array}{c}0.390 * * * \\
(0.068)\end{array}$ & $\begin{array}{c}0.388 * * * \\
(0.073)\end{array}$ & $\begin{array}{c}0.362 * * * \\
(0.071)\end{array}$ & $\begin{array}{c}0.372 * * * \\
(0.073)\end{array}$ & $\begin{array}{c}0.335^{* * *} \\
(0.068)\end{array}$ & $\begin{array}{c}0.404 * * * \\
(0.075)\end{array}$ & $\begin{array}{c}0.336 * * * \\
(0.065)\end{array}$ & $\begin{array}{c}0.401 * * * \\
(0.071)\end{array}$ & $\begin{array}{c}0.456^{* * *} \\
(0.096)\end{array}$ & $\begin{array}{c}0.308 * * * \\
(0.055)\end{array}$ & $\begin{array}{c}0.398 * * * \\
(0.072)\end{array}$ & $\begin{array}{r}0.405^{* * *} \\
(0.082)\end{array}$ \\
\hline 1st stage F-test & 32.590 & 28.130 & 26.343 & 25.828 & 23.950 & 28.824 & 27.091 & 31.972 & 22.563 & 31.466 & 30.519 & 24.593 \\
\hline P-value & 0.000 & 0.000 & 0.000 & 0.000 & 0.000 & 0.000 & 0.000 & 0.000 & 0.000 & 0.000 & 0.000 & 0.000 \\
\hline Observations & 44,716 & 43,544 & 43,856 & 43,764 & 43,619 & 33,978 & 44,191 & 43,075 & 34,150 & 44,253 & 43,359 & 43,121 \\
\hline
\end{tabular}


In our main specification, not all the twelve countries are included in both samples.

This is because the variable describing financial difficulties when the individual was teenager is missing in some countries in the 2005 cross section. We repeat the exercise using only the countries that appear in both cross sections. This means we exclude Austria, Greece, France, Malta, and Portugal. Again, as shown in Table O7, our results do not change.

Table 07: Using only countries in both cross-sections

\begin{tabular}{|c|c|c|c|c|c|c|c|}
\hline & $\begin{array}{c}\text { I } \\
\text { All }\end{array}$ & $\begin{array}{c}\text { II } \\
\text { Men }\end{array}$ & $\begin{array}{c}\text { III } \\
\text { Women }\end{array}$ & $\begin{array}{c}\text { IV } \\
\text { Non Poor }\end{array}$ & $\begin{array}{l}\mathrm{V} \\
\text { Poor }\end{array}$ & $\begin{array}{c}\text { VI } \\
\text { Educated }\end{array}$ & $\begin{array}{c}\text { VII } \\
\text { Non educated }\end{array}$ \\
\hline \multicolumn{8}{|c|}{ A. Dependent variable is good health reported } \\
\hline $\begin{array}{l}\text { OLS coefficient of } \\
\text { years of schooling }\end{array}$ & $\begin{array}{c}0.020 * * * \\
(0.001)\end{array}$ & $\begin{array}{c}0.017 * * * \\
(0.001)\end{array}$ & $\begin{array}{c}0.022 * * * \\
(0.001)\end{array}$ & $\begin{array}{c}0.020 * * * \\
(0.001)\end{array}$ & $\begin{array}{l}0.018 * * * \\
(0.002)\end{array}$ & $\begin{array}{c}0.024 * * * \\
(0.002)\end{array}$ & $\begin{array}{c}0.019 * * * \\
(0.001)\end{array}$ \\
\hline $\begin{array}{l}\text { IV coefficient of } \\
\text { years of schooling }\end{array}$ & $\begin{array}{c}0.046 \\
(0.055)\end{array}$ & $\begin{array}{l}-0.029 \\
(0.062)\end{array}$ & $\begin{array}{c}0.110 \\
(0.068)\end{array}$ & $\begin{array}{c}0.118 \\
(0.082)\end{array}$ & $\begin{array}{l}-0.055 \\
(0.075)\end{array}$ & $\begin{array}{c}1.145 \\
(3.572)\end{array}$ & $\begin{array}{c}0.004 \\
(0.048)\end{array}$ \\
\hline \multicolumn{8}{|c|}{ B. Dependent variable is not limited in daily activities } \\
\hline $\begin{array}{l}\text { OLS coefficient of } \\
\text { years of schooling }\end{array}$ & $\begin{array}{c}0.014^{* * * *} \\
(0.001)\end{array}$ & $\begin{array}{c}0.013 * * * \\
(0.001)\end{array}$ & $\begin{array}{c}0.014^{* * *} \\
(0.001)\end{array}$ & $\begin{array}{c}0.014 * * * \\
(0.001)\end{array}$ & $\begin{array}{c}0.013 * * * \\
(0.001)\end{array}$ & $\begin{array}{c}0.015^{* * * *} \\
(0.002)\end{array}$ & $\begin{array}{c}0.014 * * * \\
(0.001)\end{array}$ \\
\hline $\begin{array}{l}\text { IV coefficient of } \\
\text { years of schooling }\end{array}$ & $\begin{array}{c}0.028 \\
(0.048)\end{array}$ & $\begin{array}{l}-0.011 \\
(0.070)\end{array}$ & $\begin{array}{c}0.059 \\
(0.054)\end{array}$ & $\begin{array}{c}0.077 \\
(0.066)\end{array}$ & $\begin{array}{l}-0.047 \\
(0.080)\end{array}$ & $\begin{array}{l}-0.285 \\
(1.032)\end{array}$ & $\begin{array}{c}0.027 \\
(0.044)\end{array}$ \\
\hline \multicolumn{8}{|c|}{ C. Dependent variable is no chronic } \\
\hline $\begin{array}{l}\text { OLS coefficient of } \\
\text { years of schooling }\end{array}$ & $\begin{array}{c}0.009 * * * \\
(0.001)\end{array}$ & $\begin{array}{c}0.007 * * * \\
(0.001)\end{array}$ & $\begin{array}{c}0.011^{* * *} \\
(0.002)\end{array}$ & $\begin{array}{c}0.010 * * * \\
(0.001)\end{array}$ & $\begin{array}{c}0.007 * * * \\
(0.002)\end{array}$ & $\begin{array}{c}0.013 * * * \\
(0.002)\end{array}$ & $\begin{array}{c}0.009 * * * \\
(0.001)\end{array}$ \\
\hline $\begin{array}{l}\text { IV coefficient of } \\
\text { years of schooling }\end{array}$ & $\begin{array}{c}0.050 \\
(0.054)\end{array}$ & $\begin{array}{l}-0.046 \\
(0.075)\end{array}$ & $\begin{array}{l}0.139 * \\
(0.078)\end{array}$ & $\begin{array}{c}0.104 \\
(0.075)\end{array}$ & $\begin{array}{l}-0.014 \\
(0.077)\end{array}$ & $\begin{array}{c}0.578 \\
(1.642)\end{array}$ & $\begin{array}{c}0.019 \\
(0.045)\end{array}$ \\
\hline $\begin{array}{l}\text { First-Stage } \\
\text { 1st stage }\end{array}$ & $0.263 * * *$ & $0.259 * * *$ & $0.255^{* * *}$ & $0.249 * * *$ & $0.293 * *$ & 0.045 & $0.334 * * *$ \\
\hline coefficient & $(0.054)$ & $(0.091)$ & $(0.069)$ & $(0.085)$ & $(0.122)$ & $(0.109)$ & $(0.061)$ \\
\hline 1st stage F-test & 23.663 & 8.021 & 13.736 & 8.524 & 5.781 & 0.172 & 30.307 \\
\hline P-value & 0.000 & 0.006 & 0.000 & 0.004 & 0.018 & 0.679 & 0.000 \\
\hline Observations & 36,916 & 16,994 & 19,922 & 23,378 & 13,538 & 9,592 & 27,324 \\
\hline
\end{tabular}


Finally, our selection of countries does not include three countries that other authors have used. These are Denmark, Hungary, and Spain. ${ }^{33}$ We excluded these three countries because we find no effect of the reforms other authors have suggested (see Figure O3).

Figure O3: Impact of reforms on schooling: countries not selected

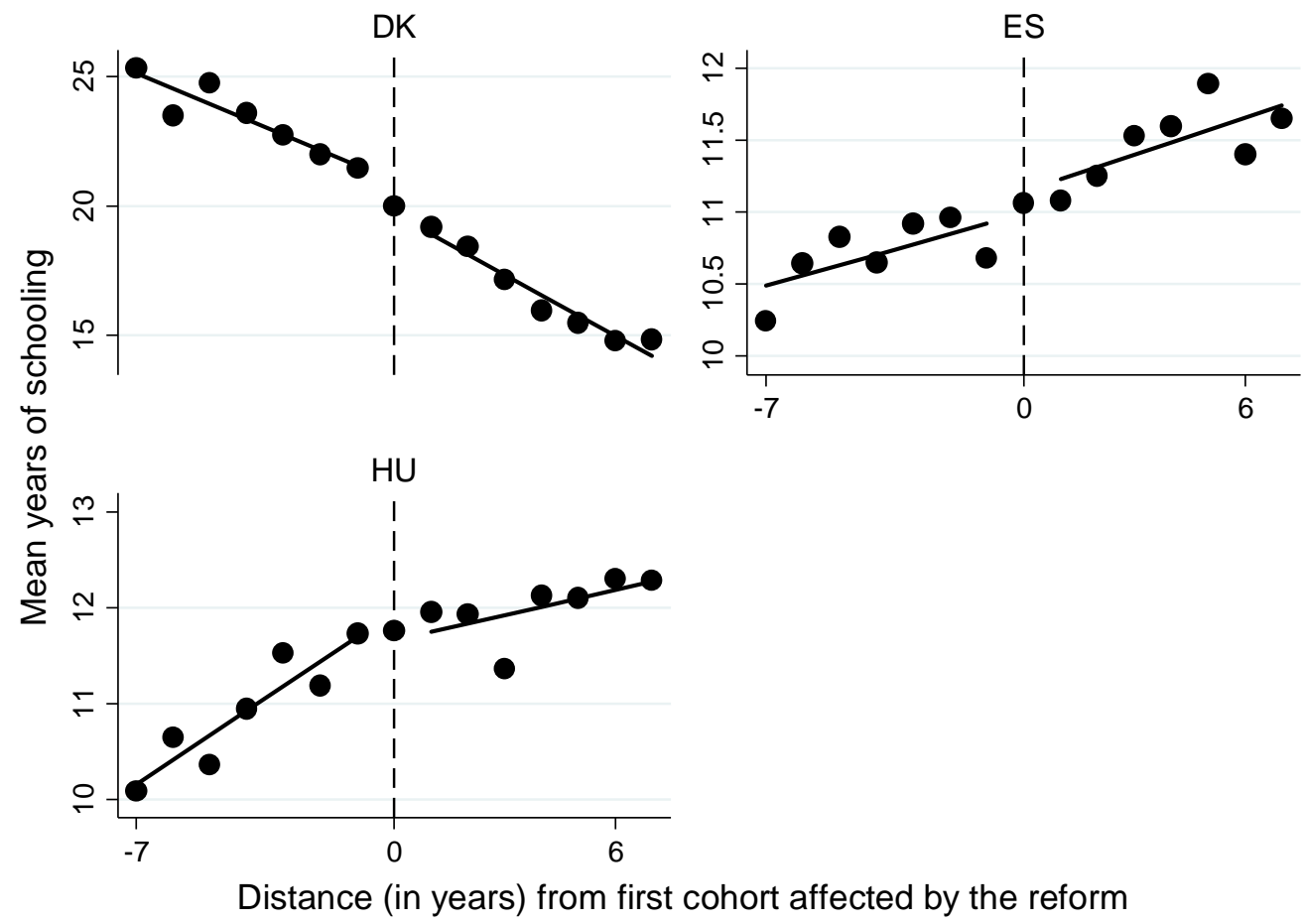

Nevertheless, we estimate again the model using these three additional countries. The results are in Table O8. In line with our finding that reforms have little effect in these three countries, we observe that the first-stage coefficient is now much lower. This coefficient is now $0.24(F=17.73)$, while in Table 2 it was $0.368(F=28.28)$, a reduction of about $1 / 3$. Still, we see no effect of education on health outcomes.

\footnotetext{
${ }^{33}$ Mocan and Pogorelova (2017) use Hungary.
} 
Table O8: Adding Denmark, Hungary, and Spain

\begin{tabular}{ccccccc}
\hline I & II & III & IV & V & VI & VII \\
All & Men & Women & Non Poor & Poor & Educated & Non educated \\
\hline
\end{tabular}

\begin{tabular}{|c|c|c|c|c|c|c|c|}
\hline \multicolumn{8}{|c|}{$\begin{array}{l}\text { A. Dependent variable is good health } \\
\text { reported }\end{array}$} \\
\hline $\begin{array}{l}\text { OLS coefficient of } \\
\text { years of schooling }\end{array}$ & $\begin{array}{c}0.019 * * * \\
(0.001)\end{array}$ & $\begin{array}{c}0.018 * * * \\
(0.001)\end{array}$ & $\begin{array}{c}0.021 * * * \\
(0.001)\end{array}$ & $\begin{array}{c}0.019 * * * \\
(0.001)\end{array}$ & $\begin{array}{c}0.019 * * * \\
(0.001)\end{array}$ & $\begin{array}{c}0.024 * * * \\
(0.002)\end{array}$ & $\begin{array}{c}0.018^{* * *} \\
(0.001)\end{array}$ \\
\hline $\begin{array}{l}\text { IV coefficient of } \\
\text { years of schooling }\end{array}$ & $\begin{array}{c}0.011 \\
(0.033)\end{array}$ & $\begin{array}{l}-0.126^{*} \\
(0.071)\end{array}$ & $\begin{array}{l}0.126^{* *} \\
(0.053)\end{array}$ & $\begin{array}{c}0.062 \\
(0.049)\end{array}$ & $\begin{array}{l}-0.043 \\
(0.051)\end{array}$ & $\begin{array}{l}-0.520 \\
(3.600)\end{array}$ & $\begin{array}{l}-0.001 \\
(0.030)\end{array}$ \\
\hline \multicolumn{8}{|c|}{ B. Dependent variable is not limited in daily activities } \\
\hline $\begin{array}{l}\text { OLS coefficient of } \\
\text { years of schooling }\end{array}$ & $\begin{array}{c}0.014 * * * \\
(0.001)\end{array}$ & $\begin{array}{c}0.014 * * * \\
(0.001)\end{array}$ & $\begin{array}{c}0.013^{* * *} \\
(0.001)\end{array}$ & $\begin{array}{c}0.013 * * * \\
(0.001)\end{array}$ & $\begin{array}{c}0.014 * * * \\
(0.001)\end{array}$ & $\begin{array}{c}0.015^{* * *} \\
(0.001)\end{array}$ & $\begin{array}{c}0.014 * * * \\
(0.001)\end{array}$ \\
\hline $\begin{array}{l}\text { IV coefficient of } \\
\text { years of schooling }\end{array}$ & $\begin{array}{l}-0.028 \\
(0.031)\end{array}$ & $\begin{array}{l}-0.072 \\
(0.058)\end{array}$ & $\begin{array}{c}0.008 \\
(0.036)\end{array}$ & $\begin{array}{c}0.021 \\
(0.041)\end{array}$ & $\begin{array}{l}-0.096 \\
(0.069)\end{array}$ & $\begin{array}{c}1.525 \\
(10.397)\end{array}$ & $\begin{array}{l}-0.007 \\
(0.023)\end{array}$ \\
\hline \multicolumn{8}{|c|}{ C. Dependent variable is no chronic } \\
\hline $\begin{array}{l}\text { OLS coefficient of } \\
\text { years of schooling }\end{array}$ & $\begin{array}{c}0.011^{* * *} \\
(0.001)\end{array}$ & $\begin{array}{c}0.010^{* * *} \\
(0.001)\end{array}$ & $\begin{array}{c}0.012 * * * \\
(0.001)\end{array}$ & $\begin{array}{c}0.011^{* * *} \\
(0.001)\end{array}$ & $\begin{array}{c}0.010 * * * \\
(0.001)\end{array}$ & $\begin{array}{c}0.013^{* * *} \\
(0.002)\end{array}$ & $\begin{array}{c}0.010 * * * \\
(0.001)\end{array}$ \\
\hline $\begin{array}{l}\text { IV coefficient of } \\
\text { years of schooling }\end{array}$ & $\begin{array}{c}0.037 \\
(0.032)\end{array}$ & $\begin{array}{l}-0.083 \\
(0.055)\end{array}$ & $\begin{array}{l}0.139 * * * \\
(0.052)\end{array}$ & $\begin{array}{l}0.100^{* *} \\
(0.051)\end{array}$ & $\begin{array}{l}-0.057 \\
(0.068)\end{array}$ & $\begin{array}{l}-1.190 \\
(7.351)\end{array}$ & $\begin{array}{c}0.020 \\
(0.028)\end{array}$ \\
\hline First-Stage & $0.240 * * *$ & $0.230 * * *$ & $0.248 * * *$ & $0.234 * * *$ & $0.278 * * *$ & -0.015 & $0.304 * * *$ \\
\hline $\begin{array}{l}\text { 1st stage } \\
\text { coefficient }\end{array}$ & $(0.057)$ & $(0.077)$ & $(0.064)$ & $(0.061)$ & $(0.101)$ & $(0.107)$ & $(0.064)$ \\
\hline 1st stage F-test & 17.735 & 8.798 & 15.080 & 14.711 & 7.518 & 0.021 & 22.621 \\
\hline P-value & 0.000 & 0.003 & 0.000 & 0.000 & 0.007 & 0.885 & 0.000 \\
\hline Observations & 60,432 & 28,211 & 32,221 & 37,823 & 22,609 & 13,670 & 46,762 \\
\hline
\end{tabular}

Robust standard errors in parentheses; *** $\mathrm{p}<0.01$, ** $\mathrm{p}<0.05,{ }^{*} \mathrm{p}<0.1$

Finally, we perform several additional robustness checks. These include estimating again our model using a window of five and nine cohorts instead of seven, excluding from our sample those individuals who are not the potential target of the reforms and performing a placebo test. See Tables O9 and Figure O4. As can be observed there, our main findings are robust to all these checks.

Table 09: Window size and potential non-compliers 
Window size

Excluding potential non-compliers

5 years 9 years Non HE Non high SES Non HE ${ }^{(i)}$

$\begin{array}{lccccc}\text { A. Dependent variable is good health reported } & & & \\ \text { OLS coefficient of } & 0.019^{* * *} & 0.019^{* * *} & 0.018^{* * *} & 0.020^{* * *} & 0.106 * * * \\ \text { years of schooling } & (0.001) & (0.001) & (0.001) & (0.001) & (0.005) \\ & & & & & \\ \text { IV coefficient of } & 0.023 & 0.018 & 0.033 & 0.019 & 0.485 \\ \text { years of schooling } & (0.032) & (0.028) & (0.033) & (0.029) & (0.518)\end{array}$

B. Dependent variable is not limited in daily activities

$\begin{array}{lccccc}\text { OLS coefficient of } & 0.014^{* * *} & 0.014^{* * *} & 0.013^{* * *} & 0.014^{* * *} & 0.076^{* * *} \\ \text { years of schooling } & (0.001) & (0.001) & (0.001) & (0.001) & (0.005) \\ \text { IV coefficient of } & 0.014 & 0.018 & 0.019 & 0.007 & 0.276 \\ \text { years of schooling } & (0.029) & (0.025) & (0.030) & (0.024) & (0.436)\end{array}$

C. Dependent variable is no

chronic

\begin{tabular}{|c|c|c|c|c|c|}
\hline $\begin{array}{l}\text { OLS coefficient of } \\
\text { years of schooling }\end{array}$ & $\begin{array}{c}0.010 * * * \\
(0.001)\end{array}$ & $\begin{array}{c}0.010 * * * \\
(0.001)\end{array}$ & $\begin{array}{c}0.009 * * * \\
(0.001)\end{array}$ & $\begin{array}{c}0.010 * * * \\
(0.001)\end{array}$ & $\begin{array}{c}0.057 * * * \\
(0.006)\end{array}$ \\
\hline $\begin{array}{l}\text { IV coefficient of } \\
\text { years of schooling }\end{array}$ & $\begin{array}{c}0.090^{* * *} \\
(0.035)\end{array}$ & $\begin{array}{c}0.053 \\
(0.034)\end{array}$ & $\begin{array}{c}0.032 \\
(0.032)\end{array}$ & $\begin{array}{c}0.027 \\
(0.029)\end{array}$ & $\begin{array}{c}0.453 \\
(0.498)\end{array}$ \\
\hline First-Stage & $0.389 * * *$ & $0.341 * * *$ & $0.345^{* * *}$ & $0.412 * * *$ & $0.025^{* *}$ \\
\hline $\begin{array}{l}\text { 1st stage } \\
\text { coefficient }\end{array}$ & $(0.107)$ & $(0.064)$ & $(0.068)$ & $(0.075)$ & $(0.01)$ \\
\hline 1st stage F-test & 13.142 & 28.427 & 26.018 & 30.345 & 6.197 \\
\hline P-value & $<0.001$ & $<0.001$ & $<0.001$ & $<0.001$ & 0.014 \\
\hline Observations & 33,441 & 57,279 & 40,933 & 40,745 & 40,933 \\
\hline
\end{tabular}

Notes: Using fewer cohorts reduces drastically the explanatory power of the reform dummy. The F statistic drops from 28.28 to 13.14, making less reliable the identification of a causal effect. We now find a positive effect (and very large) on our third measure (no chronic condition). Some false positives are of course expected when carrying out a large number of testing. Moreover, it is worth noting that we also expect a bias towards the positive and significant effect in OLS when instruments are weaker. (i) In this column we use the indicator of having completed secondary education (SE) as our measure of education.

Figure 04: Placebo tests 


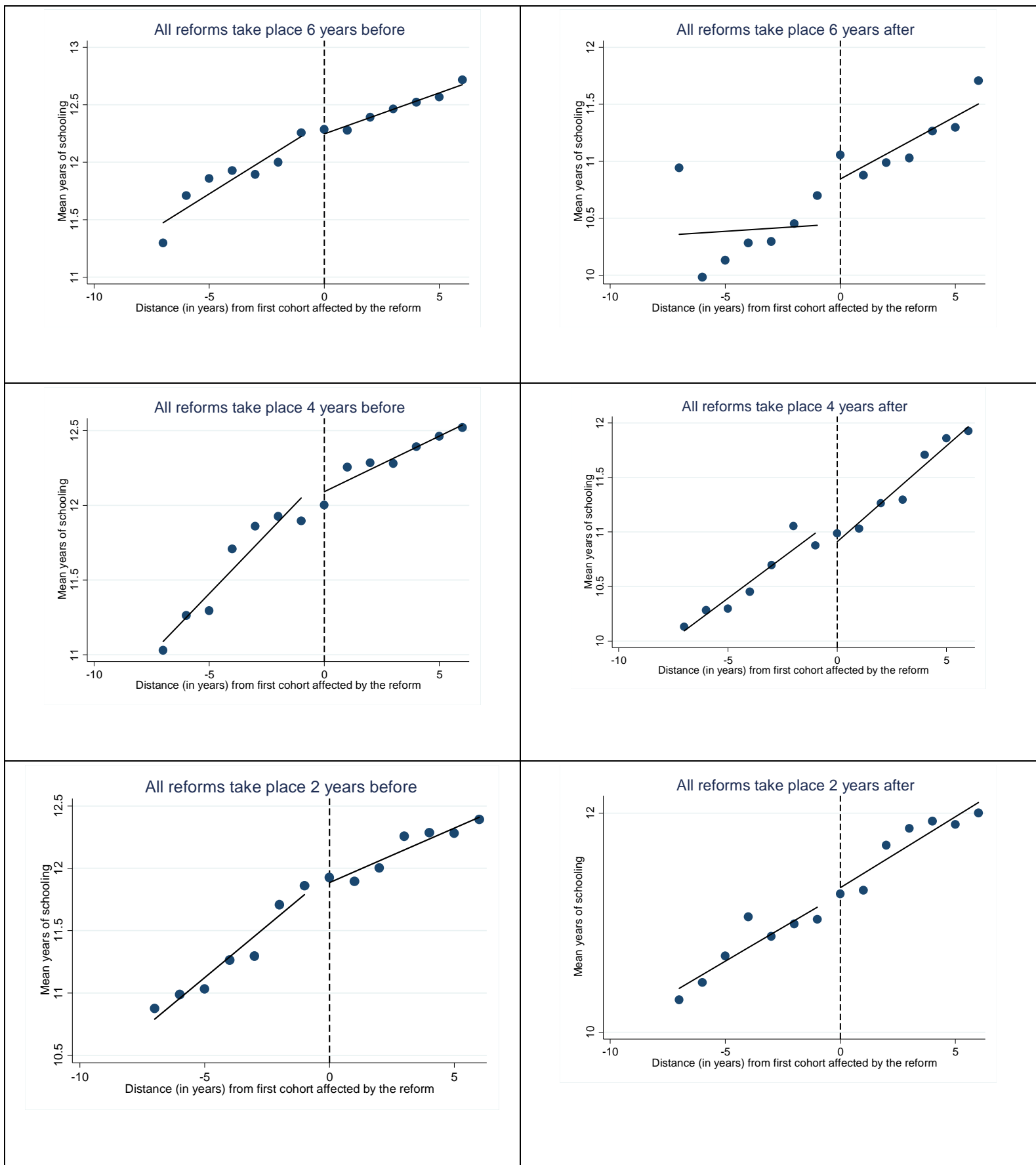

Explanation: We check if the effect of education on adult health is still maintained under circumstances in which it should not occur. In Section 5, we have seen that educational reforms have a positive effect on the schooling levels of individuals. Now, if we artificially change the dates of reforms, we should not observe an effect on schooling levels. First, we move the dates of all reforms back in time two, four and six years. Then we move them forward in time two, four and six years. For each of these six variants, we represent the effect of the reforms, as we did in Figure 2. Comparing the 


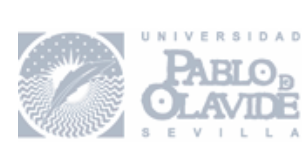

results of Figure $\mathrm{O} 4$ with those of Figure 2, we see that these artificial reforms have no effect on average schooling levels. 


\section{Additional references}

Borgonovi, F., d’Hombres, B., Hoskins, B. (2010): "Voter turnout, information acquisition and education: Evidence from 15 European countries,” The B.E. Journal of Economic Analysis and Policy 10, 1 (Contributions), Article 90.

Brandolini, A., Cipollone, P. (2002): "Return to education in Italy 1992-1997.” Working paper.

Brunello, G., Fort, M., Weber, G. (2009): “Changes in Compulsory Schooling, Education and the Distribution of Wages in Europe,” The Economic Journal 119, 516-539.

Brunello, G., Weber, G., Weiss, C. (2017): “Books are forever: early life conditions, education and lifetime earnings in Europe,” The Economic Journal 127, 271-296.

Carneiro, P., Meghir, C., Parey, M. (2013): “Maternal Education, Home Environments, and the Development of Children and Adolescents,” Journal of the European Economic Association 11, 123-160.

Cavaille, C., Marshall, J. (2019): “Education and Anti-Immigration Attitudes: Evidence from Compulsory Schooling Reforms across Western Europe,” American Political Science Review 113(1), 254-263.

Fort, M. (2006): “Educational Reforms across Europe: A Toolbox for Empirical Research.” Mimeo, Paper version: May 11, 2006.

Fort, M., Schneeweis, N., Winter-Ebmer, R. (2016): "Is Education Always Reducing Fertility? Evidence from Compulsory Schooling Reforms,” The Economic Journal 126, 1823-1855. 


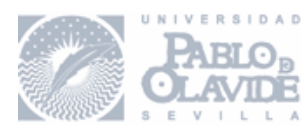

Garrouste, C. (2010): “100 years of educational reforms in Europe: A contextual database,” European Commission Joint Research Center, Luxembourg: Publications, Office of the European Union.

Grenet, J. (2013): “Is Extending Compulsory Schooling Alone Enough to Raise Earnings? Evidence from French and British Compulsory Schooling Laws.” Scandinavian Journal of Economics 115, 1, 176-210.

d'Hombres, B., Nunziata, L. (2016): “Wish You Were Here? Quasi-Experimental Evidence on the Effect of Education on Attitude toward Immigrants,” European Economic Review 90, 201-224.

Kallen, D. (1998): “Secondary education in Europe: Problems and prospects,” Council of Europe.

Meyer, A. (2017): “The impact of education on political ideology: Evidence from European compulsory education reforms,” Economics of Education Review 56, 9-23.

Murtin, F., Viarengo, M. (2011): “The Expansion and Convergence of Compulsory Schooling in Western Europe: 1950-2000,” Economica 78, 311, 501-522.

Vieira, J. (1999): “Returns to education in Portugal,” Labour Economics 6, 4, 535-541. 